\title{
U2AF homology motifs: protein recognition in the RRM world
}

\author{
Clara L. Kielkopf, ${ }^{1,3}$ Stephan Lücke, ${ }^{2}$ and Michael R. Green ${ }^{2,4}$ \\ ${ }^{1}$ Department of Biochemistry and Molecular Biology, Johns Hopkins University Bloomberg School of Public Health, \\ Baltimore, Maryland 21205, USA; ${ }^{2}$ Howard Hughes Medical Institute, Programs in Gene Function and Expression and \\ Molecular Medicine, University of Massachusetts Medical School, Worcester, Massachusetts 01605, USA
}

\begin{abstract}
Recent structures of the heterodimeric splicing factor U2 snRNP auxiliary factor (U2AF) have revealed two unexpected examples of RNA recognition motif (RRM)-like domains with specialized features for protein recognition. These unusual RRMs, called U2AF homology motifs (UHMs), represent a novel class of protein recognition motifs. Defining a set of rules to distinguish traditional RRMs from UHMs is key to identifying novel UHM family members. Here we review the critical sequence features necessary to mediate protein-UHM interactions, and perform comprehensive database searches to identify new members of the UHM family. The resulting implications for the functional and evolutionary relationships among candidate UHM family members are discussed.
\end{abstract}

The processes of RNA splicing, transport, capping, editing, and polyadenylation are heavily dependent on protein factors that recognize the pre-mRNA and assemble the appropriate pre-mRNA processing complexes. Surprisingly, the many different protein factors that guide pre-mRNA modification pathways are composed of a limited number of conserved, modular RNA-binding domains (Burd and Dreyfuss 1994). Of these, the RNA recognition motif (RRM) domain is by far the most abundant type of eukaryotic RNA-binding motif. In addition to associations between protein and RNA, protein-protein interactions are essential to recruit catalytic components to sites of RNA modification and to coordinate pre-mRNA processing with other cellular pathways. Interestingly, traditional protein interaction domains, such as SH2, SH3, and WW motifs, are rarely observed in pre-mRNA processing factors (e.g., see Shatkin and Manley 2000; Zhou et al. 2002), implying that the ability to interact with other proteins may reside in the sequences previously thought to be involved in RNA binding. Con-

[Keywords: U2AF; RNA recognition motif; protein-protein interaction, RNA-binding domain; PUMP; splicing factor] Corresponding authors.

${ }^{3}$ E-MAIL ckielkop@jhsph.edu; FAX (410) 955-2926.

${ }^{4}$ E-MAIL michael.green@umassmed.edu; FAX (508) 856-5473.

Article and publication are at http://www.genesdev.org/cgi/doi/10.1101/ gad.1206204 sistent with this idea, recent structures of the heterodimeric splicing factor $\mathrm{U} 2$ snRNP auxiliary factor (U2AF) have revealed two unexpected examples of RRM-like domains with specialized features for protein recognition (Kielkopf et al. 2001; Selenko et al. 2003). In light of this structural information, we call these unusual RRMs U2AF homology motifs (UHMs) to reflect their distinct role in protein recognition. Here, the critical sequence features necessary to mediate protein-UHM interactions are reviewed and formulated in a manner that has permitted a comprehensive database search designed to identify members of the UHM family. The resulting implications for the functional and evolutionary relationships among candidate members of the UHM family are discussed. This review represents a first step toward distinguishing canonical RRMs from UHMs, and thereby contributes toward a major goal of the postgenomic era (Thornton et al. 2000): to convert genomic sequences into testable functional hypotheses.

\section{Structural features of RNA recognition by canonical RRMs}

The RNA-binding function of the canonical RRM domain has been extensively investigated over the last two decades. The most conserved RRM signature sequence is an eight-residue motif called ribonucleoprotein 1 (RNP1; Adam et al. 1986; Sachs et al. 1986), which has the consensus [RK]-G-[FY]-[GA]-[FY]-[ILV]-X-[FY] (where $\mathrm{X}$ is any amino acid). A second six-residue region of homology, called RNP2, is typically located $\sim 30$ residues Nterminal to RNP1 (Lahiri and Thomas 1986; Dreyfuss et al. 1988), and has the consensus [ILV]-[FY]-[ILV]-X-N-L. Additional conserved amino acids define an $\sim 80$-residue domain that encompasses the RNA-binding function (Query et al. 1989; Scherly et al. 1989; Birney et al. 1993).

The three-dimensional structure of the canonical RRM domain was first determined for the RRM of U1A (Nagai et al. 1990; Hoffman et al. 1991). The RRM fold is composed of two $\alpha$-helices packed against four antiparallel $\beta$-strands with topology $\beta \alpha \beta \beta \alpha \beta$, which form an $\alpha / \beta$ sandwich (Fig. 1). The RNP consensus motifs form two central $\beta$-strands, with RNP1 in $\beta 3$ and RNP2 in $\beta 1$. Because of the alternating side-chain conformations of 
Kielkopf et al.

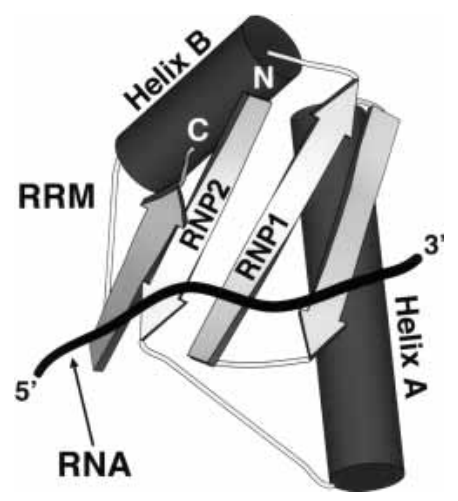

Figure 1. Representative canonical RRM fold, from the structure of the U1A/RNA complex (PDB code IURN). The N- and $\mathrm{C}$-terminal ends of the RRM are indicated. The position and orientation of the RNA are represented with a ribbon diagram.

the pleated $\beta$-sheet, some of the consensus residues maintain the core fold, whereas others are displayed on the surface for nucleic acid recognition. Structures of single RRMs complexed with RNA have been determined for the U1A-RRM bound to a hairpin loop of U1 snRNA /Oubridge et al. 1994; Price et al. 1998; Deo et al. 1999; Handa et al. 1999; Allain et al. 2000; Wang and Tanaka Hall 2001), and for a ternary complex of the U2 snRNP proteins U2B"-RRM/U2A' with a U2 snRNA hairpin loop (Price et al. 1998). In contrast to the isolated RRM of U1A, in most cases multiple RRMs are observed within a single polypeptide, with an average of two RRMs per protein (Letunic et al. 2004). The structures of several proteins composed of two tandem RRMs complexed with single-stranded RNA oligonucleotides have been determined, including the alternative splicing factor Sxl (Handa et al. 1999), PAB (Deo et al. 1999), prerRNA packaging protein nucleolin (Allain et al. 2000), and translation regulatory protein $\mathrm{HuD}$ /Wang and Tanaka Hall 2001). A comparison of these six different structures has revealed some common themes, as well as differences, in the mode of canonical RRM/RNA recognition. When all the structures are superimposed, structural equivalent hydrogen-bonds or stacking interactions are observed between single-stranded RNA and residues in the RNP1 and RNP2 motifs. A variety of sequences and RNA conformations are recognized by a variety of complementary hydrogen bonds with specific bases and differing arrangements of single or multiple RRMs.

\section{$\mathrm{U} 2 \mathrm{AF}$, the UHM prototype}

During pre-mRNA splicing, U2AF and other essential factors facilitate sequential association of small nuclear RNP particles (snRNPs), including U1, U2, U4, U5, and U6 snRNPs, with the borders of intervening pre-mRNA sequences (for review, see Brow 2002). Following assembly of the functional spliceosome, the intron is excised as a branched lariat by two catalytic steps, and adjacent exons are joined together to form the spliced mRNA.
U2AF was identified as a factor that binds to pre-mRNA consensus sequences at the $3^{\prime}$ splice site (3'SS), and is required for stable association of the $\mathrm{U} 2 \mathrm{snRNP}$ core spliceosome particle with the pre-mRNA branch point sequence (BPS) during the first ATP-dependent step of the splicing process (Complex A; Ruskin et al. 1988; Zamore and Green 1989). The importance of U2AF in vitro was soon corroborated by the discovery that both subunits are essential in Drosophila melanogaster (Kanaar et al. 1993; Rudner et al. 1996, 1998b) and Caenorhabditis elegans (Zorio and Blumenthal 1999b). Moreover, U2AF ${ }^{65}$ is an essential protein in Schizosaccharomyces pombe (Potashkin et al. 1993), and U2AF $\mathrm{AF}^{35}$ is necessary for vertebrate development (Golling et al. 2002). Because U2AF commits the pre-mRNA to the first critical ATP-dependent step of splicing, its binding is often regulated during alternative splicing (Smith and Valcarcel 2000). In humans, the products of five $\mathrm{U}_{2} \mathrm{AF}^{35}$-like open reading frames and the single $\mathrm{U}_{2} \mathrm{AF}^{65}$ subunit may form distinct heterodimers with different functional activities (Tupler et al. 2001; Shepard et al. 2002). In addition to U2AF, other non-snRNP protein factors are required for formation of Complex A, including Splicing Factor 1 (SF1) and Splicing Factor 3b (SF3b), a multisubunit component of the U2 snRNP (Kramer and Utans 1991).

To perform its role in RNA splicing, two central canonical RRM domains of $\mathrm{U}_{2} \mathrm{AF}^{65}$ recognize the polypyrimidine tract (Py-tract) in the pre-mRNA (Fig. 2). Binding of $\mathrm{U}_{2} \mathrm{AF}^{65}$ to the Py-tract is strengthened by cooperative protein-protein interactions with SF1 at the upstream BPS (Berglund et al. 1998; Rain et al. 1998) and with $\mathrm{U} 2 \mathrm{AF}^{35}$, which contacts the downstream 3'SS con-

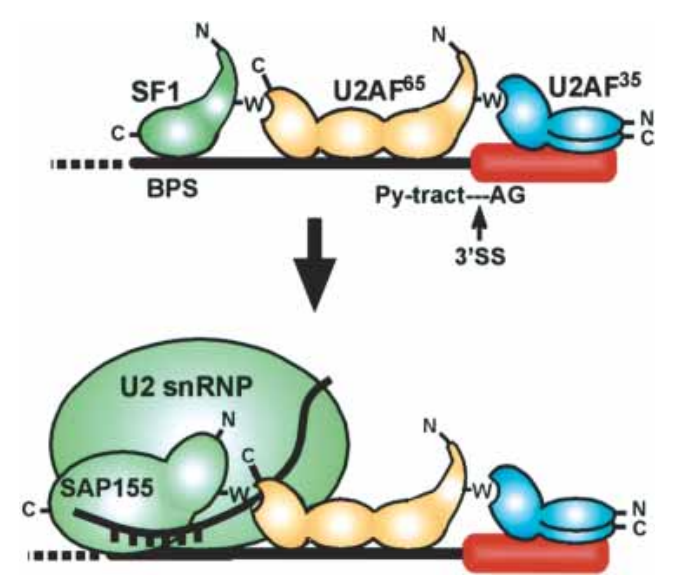

Figure 2. Diagram of protein-protein interactions mediated by the U2AF heterodimer during the initial stages of pre-mRNA splicing. The U2AF heterodimer (mediated by the $\mathrm{U}_{2} \mathrm{AF}^{35}$. $\mathrm{UHM} / \mathrm{U} 2 \mathrm{AF}^{65}$-ligand interaction) binding to the poly-pyrimidine tract (Py-tract) and $3^{\prime}$-splice site (3'SS) is facilitated by cooperative interactions between the $\mathrm{U}_{2} \mathrm{AF}^{65}-\mathrm{UHM}$ and SF1 at the branchpoint sequence (BPS). Subsequently, SF1 interactions with the $\mathrm{U}_{2} \mathrm{AF}^{65}-\mathrm{UHM}$ are replaced by SAP155. The N- and C-terminal ends of the proteins are indicated; the conserved ligand Trp residue $(\mathrm{W})$ is also shown (discussed further in the text). 
sensus (Merendino et al. 1999; Wu et al. 1999; Zorio and Blumenthal 1999a). The C-terminal UHM domain of $\mathrm{U} 2 \mathrm{AF}^{65}$ interacts with the $\mathrm{N}$-terminal domain of SF1 (U2AF ${ }^{65}$-UHM/SF1-ligand; Rain et al. 1998). At the opposite end of the large subunit, the $\mathrm{N}$-terminal domain of $\mathrm{U} 2 \mathrm{AF}^{65}$ provides a ligand that interacts with the central $\mathrm{UHM}$ domain of $\mathrm{U}_{2} \mathrm{AF}^{35}$ (U2AF $\mathrm{AF}^{35}$-UHM/U2AF ${ }^{65}$-ligand; Zhang et al. 1992; Rudner et al. 1998b). Subsequently, entry of the U2 snRNP displaces SF1 by interacting with the BPS via the U2 snRNA (Nelson and Green 1989; Wu and Manley 1989; Zhuang and Weiner 1989; Query et al. 1994), and with the U2AF ${ }^{65}$ C-terminal domain via the SF3b subunit, SAP155 (Gozani et al. 1998; Habara et al. 1998). Once the U2 snRNP has contacted the premRNA, U2AF is dissociated by conformational rearrangements of the spliceosome components (Bennett et al. 1992; Chiara et al. 1997). In summary, key proteinprotein interactions are mediated by the $\mathrm{U}_{2} \mathrm{AF}^{65}-\mathrm{UHM}$, which interacts with SF1 and subsequently SAP155, and by the U2AF ${ }^{35}$-UHM, which interacts with the U2AF ${ }^{65}$ $\mathrm{N}$ terminus.

\section{Structural features of protein-protein interactions by UHMs}

Based on primary sequence analysis, both the $U 2 \mathrm{AF}^{65}$ C-terminal domain and the central domain of $\mathrm{U}_{2} \mathrm{AF}^{35}$ were suspected to contain unusual variations of the RRM fold (Birney et al. 1993). However, the borders of the U2AF-UHM domains could not be assigned accurately because of sequence insertions in the first helix of the fold (Helix A) and the absence of aromatic amino acids in the RNP-like motifs that are normally critical for RNA recognition. The independent determination of the X-ray structure of the $\mathrm{U}_{2} \mathrm{AF}^{35}$-UHM/U2 $\mathrm{AF}^{65}$-ligand complex (Kielkopf et al. 2001) and NMR structure of the U2AF ${ }^{65}$-UHM/SF1-ligand complex (Selenko et al. 2003) confirmed that both the C-terminal $\mathrm{U}_{2} \mathrm{AF}^{65}$ and central $\mathrm{U}_{2} \mathrm{AF}^{35}$ protein interaction domains adopt the $\beta \alpha \beta \beta \alpha \beta$ RRM-fold topology. Within the RRM-like fold, the sequence insertions separating the RNP-like motifs increase the length of Helix A from three turns observed among canonical RRMs to five or eight turns for $\mathrm{U}_{2} \mathrm{AF}^{65}$ and $\mathrm{U}_{2} \mathrm{AF}^{35}$, respectively; the functional role of these sequence insertions, if any, is unclear. The parallel use of an RRM-like fold to recognize similar peptide ligands implies that the U2AF ${ }^{35}-\mathrm{UHM}$ and $\mathrm{U} 2 \mathrm{AF}^{65}-\mathrm{UHM}$ domains represent a new type of protein-protein interaction motif, hitherto undetected amid the many canonical RRMs of pre-mRNA processing factors.

Three-dimensional structural information revealed unanticipated sequence features of $\mathrm{U}_{2} \mathrm{AF}^{35}-\mathrm{UHM}$ and $\mathrm{U} 2 \mathrm{AF}^{65}$-UHM domains that enable interaction with short protein ligands. Despite low primary sequence identity $(23 \%)$, ligand recognition by the different UHM domains is very similar (Fig. 3). In both the U2AF ${ }^{35}$ $\mathrm{UHM} / \mathrm{U} 2 \mathrm{AF}^{65}$-ligand and $\mathrm{U}_{2} \mathrm{AF}^{65}$-UHM/SF1-ligand structures, a critical Trp residue in the ligand sequence inserts into a tight hydrophobic pocket between the $\alpha$-helices and the RNP1- and RNP2-like motifs (Kielkopf et al. 2001; Selenko et al. 2003). In addition to aliphatic residues, a conserved Arg-X-Phe motif (where $\mathbf{X}$ is any amino acid; see below) on the loop connecting the last $\alpha$-helix (Helix B) and $\beta$-strand of the UHM fold contributes to the Trp-binding pocket. The Arg residue in the loop (U2AF $\mathrm{AF}^{35}$-Arg 133 or $\mathrm{U}_{2} \mathrm{AF}^{65}$-Arg 452) forms an intramolecular salt bridge with the last Glu residue of Helix A (U2AF ${ }^{35}$-Glu 88 or $\mathrm{U}_{2} \mathrm{AF}^{65}$-Glu 405) that shields one face of the ligand-Trp, whereas the Phe residue (U2AF ${ }^{35}$-Phe 135 or U2AF ${ }^{65}$-Phe 454) encloses the opposite Trp face. In addition to the extensive interface with the ligand-Trp, a series of acidic residues in Helix A of the UHM interacts with basic residues at the $\mathrm{N}$ terminus of the protein ligand. Specifically, electrostatic interactions between $\mathrm{U}_{2} \mathrm{AF}^{35}$-Glu 84 and $\mathrm{U}_{2} \mathrm{AF}^{65}$-Lys 90 as well as U2AF ${ }^{65}$-Asp 401 and SF1-Arg 21 are observed at similar positions for both structures. The essential nature of acidic residues within Helix A, Phe 454, and the Trp-binding pocket was confirmed for the $\mathrm{U}_{2} \mathrm{AF}^{65}$. UHM/SF1-ligand complex by site-directed mutagenesis of the U2AF $\mathrm{AF}^{65}-\mathrm{UHM}$ or SF1-ligand followed by pulldown assays (Selenko et al. 2003). Likewise, the U2AF ${ }^{65}$ ligand-Trp 92 was found to contribute two orders of magnitude to the affinity of the $\mathrm{U}_{2} \mathrm{AF}^{35}-\mathrm{UHM} / \mathrm{U} 2 \mathrm{AF}^{65}$-ligand complex by isothermal titration calorimetry.

In the U2AF ${ }^{35}-\mathrm{UHM}$, a distinctive Trp residue $\left(\mathrm{U}_{2} \mathrm{AF}^{35}\right.$-Trp 134) is observed at the $\mathbf{X}$ position of the Arg-X-Phe motif on the last loop of the UHM domain. Bulky aromatic residues such as Trp at this solvent-exposed position are especially rare among canonical RRM domains (1\% of 676 annotated RRM domains in the SWISS-PROT database). The most frequently observed residues at the corresponding position of canonical RRMs are highly charged, including Glu (16\%) and Lys $(15 \%)$, as is also observed for the U2AF ${ }^{65}$-UHM (ArgLys-Phe). The unusual U2AF ${ }^{35}$-Trp 134 inserts between a series of unique Pro residues at the $\mathrm{C}$ terminus of the $\mathrm{U} 2 \mathrm{AF}^{65}$-ligand, which are completely absent from the SF1-ligand of the U2AF ${ }^{65}$-UHM. The additional Trp/Pro interaction significantly contributes to the high affinity of the U2AF heterodimer $1.7 \mathrm{nM} \mathrm{Kd}$; Kielkopf et al. 2001). Because the U2AF ${ }^{65}$-UHM/SF1-ligand complex lacks the corresponding Trp/Pro interaction, the affinity is relatively weak ( 100 nM Kd; Selenko et al. 2003). The sequence differences in the ligands recognized by the $\mathrm{U} 2 \mathrm{AF}^{35}-\mathrm{UHM}$ and $\mathrm{U}_{2} \mathrm{AF}^{65}-\mathrm{UHM}$ domains reflect the different functional roles of the complexes, which, respectively, maintain the constitutive U2AF ${ }^{35}$-UHM/ $\mathrm{U}_{2} \mathrm{AF}^{65}$ heterodimer (Zhang et al. 1992; Rudner et al. $1998 \mathrm{~b}$ ) or form a transient $\mathrm{U} 2 \mathrm{AF}^{65} / \mathrm{SF} 1$ intermediate during spliceosome assembly (Rutz and Seraphin 1999).

The structures of the $\mathrm{U}_{2} \mathrm{AF}^{35}-\mathrm{UHM} / \mathrm{U} 2 \mathrm{AF}^{65}$-ligand and $\mathrm{U}_{2} \mathrm{AF}^{65}-\mathrm{UHM} / \mathrm{SF} 1$-ligand complexes revealed several sequence features that distinguish UHMs from canonical RRM domains. One striking feature of UHM domains is their atypical RNP-like motifs. The first residue of the RNP1-like motif and the second residue of the RNP2-like motif are unusual in that they are exposed on the $\beta$-sheet surface rather than directly involved in RNA binding. Residues in these positions consist of aliphatic 
Kielkopf et al.
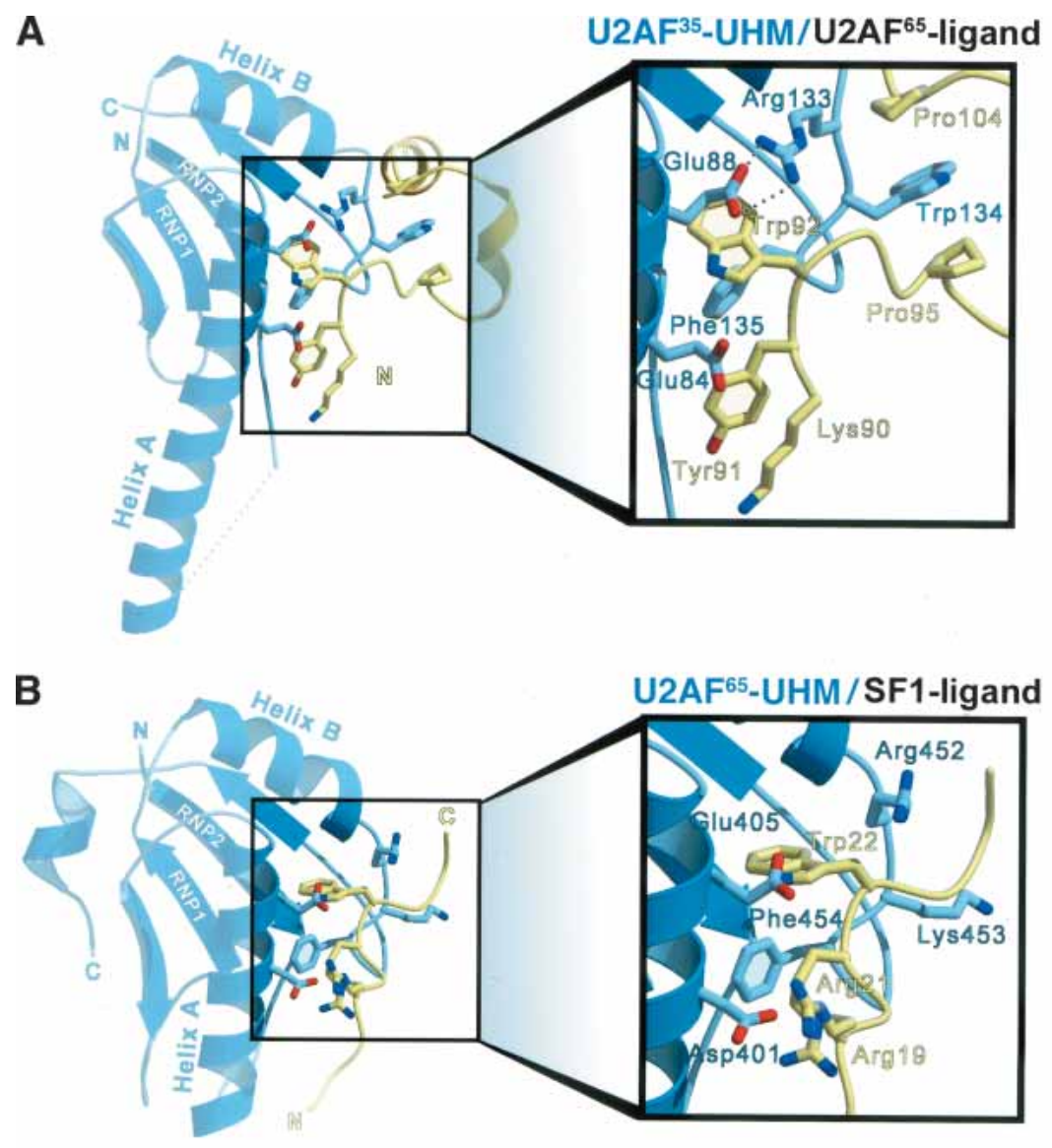

C

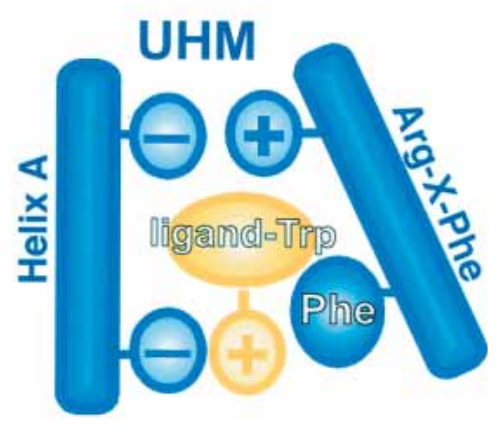

Figure 3. Structures of U2AF-UHM/ligand complexes. The UHM is shown in blue, the protein ligand is shown in yellow. Key interacting side chains are drawn in ball-and-stick representation. (A) The U2AF ${ }^{35}$-UHM bound to the $\mathrm{U}_{2} \mathrm{AF}^{65}$-ligand. $(B)$ The $\mathrm{U}_{2} \mathrm{AF}^{65}$-UHM bound to the SF1-ligand. $(C)$ Schematic representation of signature UHM protein-protein interactions shared by the two complexes.

amino acids $\left(\mathrm{U}_{2} \mathrm{AF}^{35}\right.$-Ala 47, Val 110, or $\mathrm{U}_{2} \mathrm{AF}^{65}$-Cys 379 , Cys 429) as opposed to the basic and aromatic residues used for RNA recognition by canonical RRM domains. Other prominent distinguishing sequences include the Arg-X-Phe motif and acidic residues in Helix A (especially U2AF ${ }^{35}$-Glu $84 /$ Glu 88 and $\mathrm{U}_{2} \mathrm{AF}^{65}$-Asp 401/Glu 405). As a consequence of the acidic nature of Helix A and lack of a basic RNP1 residue that usually contacts the RNA, the isoelectric points of UHM domains are remarkably low (pI 4.1 for the U2AF ${ }^{35}$-UHM and $\mathrm{pI} 4.3$ for the $\mathrm{U}_{2} \mathrm{AF}^{65}$-UHM) compared with the typically basic character of canonical RRMs $(\mathrm{pI}>9)$ that function to bind anionic RNA ligands. The majority of the aliphatic residues lining the Trp-binding pocket (including $\mathrm{U}_{2} \mathrm{AF}^{35}$-UHM Leu 48, Val 85, Leu 130, and Ile 140 and their $\mathrm{U}_{2} \mathrm{AF}^{65}$-UHM counterparts Leu 380, Val 402, Leu 449, and Val 459), however, cannot be used to dis- tinguish UHM from canonical RRM domains, because they also serve to preserve the RRM fold (Birney et al. 1993). One exception is the last aliphatic residue of the RNP2 motif (U2AF ${ }^{35}$-Ile 51 or $\mathrm{U}_{2} \mathrm{AF}^{65}$-Met 383 ), which contributes to the Trp-binding pocket and consequently differs from the conserved RNP2-Leu residue within the hydrophobic core of canonical RRM domains. Thus, at least three major sequence differences required for UHM-protein interactions distinguish UHMs from canonical RRM domains: (1) atypical RNP-like motifs, (2) an Arg-X-Phe motif in the last loop, and (3) an acidic character of Helix A.

\section{Identifying novel UHM family members}

The discovery of two examples of RRM-like domains with specialized sequence characteristics for protein- 
protein interactions raised the question of whether the $\mathrm{U} 2 \mathrm{AF}^{35}-\mathrm{UHM}$ and $\mathrm{U}_{2} \mathrm{AF}^{65}-\mathrm{UHM}$ domains represented a larger family of modular protein interaction domains. Examples of proteins with domains similar to the $\mathrm{U} 2 \mathrm{AF}^{65}$ or $\mathrm{U} 2 \mathrm{AF}^{35}-\mathrm{UHM}$ had been previously noted (Kielkopf et al. 2001; Selenko et al. 2003), including the C-terminal homodimerization domain of PUF60, which has previously been referred to as the PUF60, U2AF ${ }^{65}$, MUD2 protein-protein interaction (PUMP) domain (Page-McCaw et al. 1999). Several search strategies were used to further extend the UHM family. An initial consensus pattern for the U2AF ${ }^{65}, \mathrm{U}_{2} \mathrm{AF}^{35}$, PUF60, and TatSF1 UHM domains, defined automatically using the program PRATT (Brazma et al. 1996), proved too stringent as it only matched homologs of these proteins in a ScanProSite search of the SWISS-PROT/TrEMBL databases (Gattiker et al. 2002). Therefore, a target pattern ([ILMVFC]-X-[LIFV]-X-[NSHT]-[ILMVC]-X(6,40)-[VLIT]-X(2)[ED]-X(4,5)-G-X-[IVA]-X(4)-[VIL]-X(4,25)-[GV]-X-[VIAL][FY]-[VIL]-X-[FYC]-X(6,12)-[AC]-[LVMIC]-X-X-[LMIF]-X[NG]-R-[WYKM]-[FY]-X-G-X(4,8)-[IVL]) was defined manually based upon conserved residues that either maintain the RRM-like fold (Birney et al. 1993) or mediate protein-protein interactions in the structures of $\mathrm{U} 2 \mathrm{AF}^{35}$-UHM/U2AF ${ }^{65}$-ligand and U2AF ${ }^{65}$-UHM/SF1-ligand (Kielkopf et al. 2001; Selenko et al. 2003). A search of the SWISS-PROT/TrEMBL databases with this target pattern identified several novel UHM candidates. The UHM family was further extended by manually inspecting RRM family alignments (Prosite PS50102) and the results of iterative PHI-PSI BLAST searches (Altschul et al. 1997) for similarities to the signature Arg-X-Phe motif observed in the last loop of the prototype U2AF-UHM domains.

Sequence comparisons revealed that the principal features that distinguish UHM candidates from canonical RRMs are conserved among 12 novel UHM candidates (Table 1; Fig. 4A), including (1) poor conservation of amino acids in the RNP1- and RNP2-like consensus motifs that would normally bind RNA (first/third and second positions, respectively); (2) an Arg-X-Phe motif in the last loop of the RRM-like fold; and (3) conserved acidic residues in the predicted Helix $\mathrm{A}$ and a low isoelectric point (average pI $\sim 4.5$ ). Seven additional UHM candidates displayed a subset of the UHM characteristics. To further investigate the evolutionary relationship among members of the UHM and RRM families, a phylogenetic tree of the candidates was constructed using neighbor joining with correction for multiple substitutions (Fig. 4B; Thompson et al. 1997). A comparison with canonical RRMs whose role in RNA recognition has been established by structure determination (including $\mathrm{U} 1 \mathrm{~A}, \mathrm{SXL}, \mathrm{PAB}, \mathrm{HuD}$, and nucleolin) revealed that the 12 convincing UHM candidates occupy a phylogenetic branch distinct from canonical RRMs that diverged from a common ancestral domain. The dendrogram also confirms that several of the putative UHM candidates (i.e., those that displayed only a subset of the UHM characteristics) are more closely related to canonical RRM domains than to U2AF or other UHM candidates, indicat- ing that these proteins may have independently evolved UHM-like sequence motifs. Additional proteins from diverse eukaryotes displayed UHM signature sequences, but were considered homologs of other UHM candidates based on high sequence identity (Table 2). Given the difficulty of distinguishing UHMs from canonical RRM domains based on primary sequence comparisons alone, additional UHM protein interaction domains may be hidden within the RRM superfamily.

In a few cases, UHM candidates that share a similar domain organization may represent homologs despite low sequence identities and/or a lack of consistent functional data, including SPF45 and DRT111; HCC1 and PAD1; TAT-SF1, UAP2, and CUS2; and MUD2 and $\mathrm{U}_{2} \mathrm{AF}^{65}$. In a well-studied example, MUD2 is the $S$. cerevisiae homolog of $\mathrm{U}_{2} \mathrm{AF}^{65}$ based on similar functional interactions with the Py-tract, U2 snRNP, and SF1 (Abovich et al. 1994; Rain et al. 1998). Despite low sequence identity $(16 \%)$, heterologous complexes between MUD2 and human SF1, or between $S$. cerevisiae SF1 and human $\mathrm{U} 2 \mathrm{AF}^{65}$ have not been observed (Rain et al. 1998) indicating that the ligand specificity of the human $\mathrm{U}_{2} \mathrm{AF}^{65}$. UHM has diverged from the MUD2-UHM. These differences in protein-protein interaction specificity are consistent with functional divergence of MUD2 from other U2AF large subunits. For example, MUD2 is dispensable for viability in S. cerevisiae (Abovich et al. 1994), whereas the UHM domain of the $S$. pombe U2AF ${ }^{65}$ homolog (which shares $31 \%$ sequence identity with human $\mathrm{U}_{2} \mathrm{AF}^{65}$ ) is required in vivo (Banerjee et al. 2004). The $\mathrm{U}_{2} \mathrm{AF}^{65}$-UHM interacts with an $\mathrm{N}$-terminal domain of the SAP155 subunit of the U2 snRNP that is absent from the S. cerevisiae homolog of SAP155 (Gozani et al. 1998). Moreover, S. cerevisiae lacks an ortholog of the U2AF small subunit, indicating that MUD2 functions in the absence of the heterodimeric partner. These differences between $S$. cerevisiae and other U2AF homologs, coupled with the identification of eight human UHM candidates and 35 more homologs in a variety of higher eukaryotes compared with only three convincing yeast UHM candidates, suggests that the UHM diverged from the canonical RRM late in the evolutionary timeframe to serve the complicated pre-mRNA processing requirements of multicellular organisms.

The 12 candidate UHM domains are found in the context of a variety of domain arrangements within their protein sequences; a subset is detailed in Table 3 . With the exception of the central URP-UHM, the UHM domains often occur near the $\mathrm{C}$ terminus of the candidate proteins, providing an exposed position to facilitate molecular recognition. Many of the UHM candidates also contain motifs frequently observed in splicing factors, such as canonical RRMs, arginine-serine (RS) domains, zinc fingers, and Gly-rich regions. Additional unexpected domains are also observed, including the LAP2Emerin-Man1 (LEM) protein-protein interaction domain of MAN1 and kinase domain of KIS.

The diverse functional domains of the UHM candidates are accompanied by an array of different biological functions (Table 3). Like $\mathrm{U}_{2} \mathrm{AF}^{65}$ and $\mathrm{U}_{2} \mathrm{AF}^{35}$, many of 
Kielkopf et al.

Table 1. Signature sequences of UHM candidates compared with representative canonical RRMs

\begin{tabular}{|c|c|c|c|c|c|c|}
\hline UHM candidate & $\begin{array}{c}\text { Accession } \\
\text { number }\end{array}$ & RNP2 & RNP1 & $\begin{array}{l}\text { RXF } \\
\text { motif }\end{array}$ & $\begin{array}{l}\text { Acidic } \\
\text { residues }^{\mathrm{a}}\end{array}$ & $\mathrm{pI}$ \\
\hline $\mathrm{U} 2 \mathrm{AF}^{35}$ & Q01081 & IALLNI & VGNVYVKF & RWF & $y / y$ & 4.1 \\
\hline $\mathrm{U} 2 \mathrm{AF}^{65}$ & P26368 & LCLMNM & CGKIFVEF & $\mathbf{R K F}$ & $\mathrm{y} / \mathrm{y}$ & 4.3 \\
\hline \multicolumn{7}{|c|}{ UHM candidates closely related to U2AF } \\
\hline URP & BAA08533 & LLIKSM & RGNVYVQY & RWY & $y / y$ & 4.3 \\
\hline KIS & Q8TAS1 & LRLLNV & RGQVFVEY & RMF & $\mathrm{y} / \mathrm{y}$ & 4.2 \\
\hline PUF60 & AAF05605 & MVLRNM & IVKIFVEF & RWF & $\mathrm{y} / \mathrm{y}$ & 4.6 \\
\hline SPF45 & ААН 39322 & VLLRNM & AVRIFLEF & RYF & $\mathrm{y} / \mathrm{y}$ & 4.5 \\
\hline DRT111 & AAA73382 & LLLRNM & AVRIFVQF & RYF & $\mathrm{y} / \mathrm{y}$ & 4.4 \\
\hline TAT-SF1 & AAB18823 & VIIKNM & DGVASVSF & RWF & $y / y$ & 4.6 \\
\hline UAP2 & CAB38682 & VVLKHI & DGVVTVRF & RYF & $y / y$ & 4.5 \\
\hline CUS2 & CAA96203 & VIFANV & KGEATVVF & RYF & $\mathrm{y} / \mathrm{y}$ & 4.2 \\
\hline MAN1 & AAF73293 & LKIRNM & EGCVYVKC & SWF & $y / y$ & 5.8 \\
\hline HCC1 & Q14498 & FQLSNM & QGNVYVKC & RWF & $\mathrm{y} / \mathrm{y}$ & 5.7 \\
\hline PAD1 & AAD22102 & VVLHNM & AGDIYLKF & RYF & $\mathrm{y} / \mathrm{y}$ & 4.8 \\
\hline MUD2 & CAA81911 & LLLLNC & AGNIYIKF & TQF & $\mathrm{y} / \mathrm{y}$ & 4.2 \\
\hline \multicolumn{7}{|c|}{ UHM candidates distantly related to $\mathrm{U} 2 \mathrm{AF}$} \\
\hline PRP24 & AAA76605 & VFVSNL & STVALVEF & KYF & $\mathrm{n} / \mathrm{n}$ & 5.8 \\
\hline NGR1 & CAA85176 & ADLLSL & RCFGFVRF & KWF & $\mathrm{n} / \mathrm{n}$ & 9.9 \\
\hline SAP49 & ААН04273 & IFIGNL & KGYAFINF & QYL & $\mathrm{y} / \mathrm{n}$ & 4.4 \\
\hline MATRIN3 & P43243 & IHLSNL & KSQAFIEM & LWF & $\mathrm{n} / \mathrm{n}$ & 9.5 \\
\hline SRP38 & AAN65380 & LFVRNV & RGFAYVQF & KWI & $y / y$ & 7.0 \\
\hline PES4 & P39684 & IFIKNL & YLWAFVTY & FYF & $\mathrm{y} / \mathrm{n}$ & 9.7 \\
\hline TIA1 & P31483 & VFVGDL & KGYGFVSF & QWL & $\mathrm{y} / \mathrm{n}$ & 9.2 \\
\hline \multicolumn{7}{|c|}{ Canonical RRMs with known RNA comples structures } \\
\hline U1A-RRM1 & JQ1528 & IYINNL & RGQAFVIF & FPF & $\mathrm{n} / \mathrm{n}$ & 10.0 \\
\hline SXL-RRM1 & AAO39587 & LIVNYL & YGYAFVDF & ITV & $\mathrm{y} / \mathrm{n}$ & 9.7 \\
\hline SXL-RRM2 & AAO39587 & LYVTNL & RGVAFVRY & VIP & $\mathrm{n} / \mathrm{n}$ & 9.2 \\
\hline PAB-RRM1 & P11940 & LYVGDL & LGYAYVNF & DVI & $\mathrm{n} / \mathrm{n}$ & 7.0 \\
\hline PAB-RRM2 & P11940 & IFIKNL & KGYGFVHF & MLL & $\mathrm{n} / \mathrm{n}$ & 8.4 \\
\hline HUD-RRM1 & AAA58396 & LIVNYL & LGYGFVNY & LRL & $\mathrm{y} / \mathrm{n}$ & 9.3 \\
\hline HUD-RRM2 & AAA58396 & LYVSGL & RGVGFIRF & QKP & $\mathrm{y} / \mathrm{n}$ & 9.0 \\
\hline Nucleolin-RRM1 & A27441 & LFIGNL & RKFGYVDF & LKV & $\mathrm{y} / \mathrm{n}$ & 5.2 \\
\hline Nucleolin-RRM2 & A27441 & LLAKNL & KGIAYIEF & AIE & $\mathrm{y} / \mathrm{n}$ & 4.4 \\
\hline RRM consensus ${ }^{\mathrm{b}}$ & & $\Psi \Theta \Psi \times X L$ & $\oplus \mathrm{G} \Theta \Omega \Theta \Psi \times \Theta$ & $\mathrm{XXX}$ & $\mathrm{n} / \mathrm{n}$ & $>9$ \\
\hline UHM consensus $^{\mathrm{b}}$ & & $\Psi \Psi \Psi X X \Psi$ & XGX $\Psi \Theta \Psi X \Theta$ & $\oplus[\mathrm{WX}] \mathrm{F}$ & $y / y$ & $<7$ \\
\hline
\end{tabular}

Canonical RRMs were selected based on the availability of known RNA complex structures.

${ }^{a}$ Residues corresponding to $\mathrm{U}_{2} \mathrm{AF}^{35}$-Glu84/Glu88 and $\mathrm{U}_{2} \mathrm{AF}^{65}$-Asp401/Glu405.

${ }^{\mathrm{b}} \Psi$ represents aliphatic amino acids $(\mathrm{I} / \mathrm{L} / \mathrm{V}), \Theta$ aromatic amino acids $(\mathrm{F} / \mathrm{Y}), \oplus$ basic amino acids $(\mathrm{R} / \mathrm{K}), \Omega$ small amino acids $(\mathrm{G} / \mathrm{A})$, and $\mathrm{X}$ any amino acid. Shown in bold are characteristic features of UHM domains, including divergence in the second and sixth positions of the RNP2-like motif, divergence in the first and third positions of the RNP1-like motif, matches to the RXF motif, and low isoelectric point $(\mathrm{pI})$.

the UHM candidates play important roles during RNA splicing. Interestingly, a few of the candidates (PUF60, TAT-SF1, and HCC1) play a dual role in regulating transcription. Because RNA splicing factors can influence the efficiency of transcription, and conversely, transcription often influences the efficiency and products of alternative RNA splicing (Auboeuf et al. 2002; Rosonina and Blencowe 2002), these UHM candidates may couple RNA splicing with transcription to coordinate gene expression. Other candidate UHM proteins, namely, the membrane protein MAN1 and the regulatory kinase KIS, are important for signal transduction, but have not yet been shown to affect RNA processing. It remains to be determined whether KIS and MAN1 couple pre-mRNA splicing with other cellular pathways via their established roles in signal transduction. Demonstrating the significance of their functions, misregulated UHM-containing proteins are associated with several human diseases, including human immunodeficiency virus type 1 (HIV-1; Zhou and Sharp 1996), and certain cancers (Liu et al. 2001; Bieche et al. 2003; Sampath et al. 2003).

\section{Specificity of protein-protein interaction by UHM domains}

As stated above, the structures of the U2AF ${ }^{35}$-UHM and $\mathrm{U}_{2} \mathrm{AF}^{65}$-UHM complexed with their ligands revealed remarkably similar modes of protein interaction. Notably, both the $\mathrm{U}_{2} \mathrm{AF}^{65}$ and $\mathrm{SF} 1$ ligands bind their respective 
A

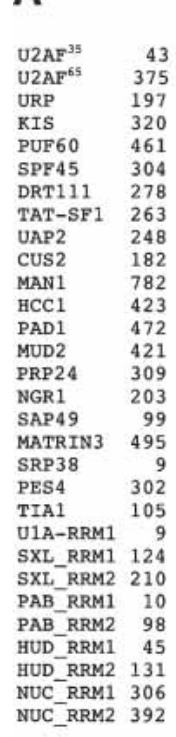

-

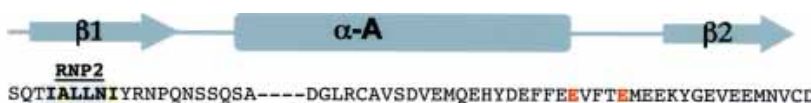

SQTIALLNIYRNPQNSSQSA----DGLRCAVSDVEMQEHYDEFFEEVFTEMEEKYGEVEEMNVCDN SPTHLIKSMFTTFGMEOCRRDDYDPDASLEYSEEETYOOFLDFYEDVLPEFK-NVGKVIOFKVSCN TPVIRLLNYLDD- DEYEDVVEDVKEECQ-KYGPVVSLLVPKE TKVVL GEVDDLEVETKEECE-KYGKVGKCVIFEI GPFHP-1-10 - MDFEDDPLVLNEIREDLRVECS-KFGQIRKLLLFDR 作 DRIVIFANVI--1-- YKSYTNDDINDIQEDLLEGCE-E IGQVDSISVSPN TPCLKIRAMP TQCFQLSMMFNP-_-_- QTEEEVGWDTEIKDDVIEECN-KHGGVIHIYVDKN SRCVVLHNMFDP-1-1-AEEEGENWIKELEDDVREEAEAKYGHVVHISLDPN SRVLLLLNCLDP-NTSVFVSNLPSD---------- VTITKVRQYFR-EYGHVNNIQLKHE ATEADLLSLFVG-_-_-_-_-_DLSPTATEADLLSLFQT-RFKSVKTVRVMTD GANIFIGNLDPE-_GRVIHLSNLPHS-_-_-_-_-_ NTSLFVRNVADD-_QNSIFIKNLPTI--HFHVFVGDLSPQ -

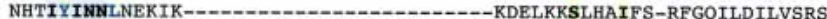
NTNLIVNYLPODMT- $-1-\ldots$ DTNLYVTNLPRTITMASLYVDLHPDVT-

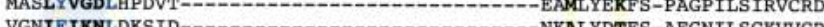
KTNE

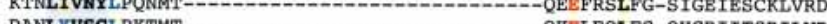
PENIF IGMUPTS ARTLLAKNLSFNIT---

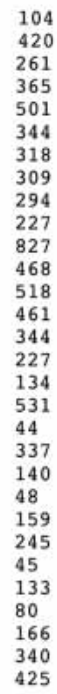

U2AF

U2AF

U2AF
URP

KIS

PUF60

SPF 45

DRT111 319

TAT-SF $1 \quad 31$

UAP2

CUS 2

MAN1

HCC1

MUD2

PRP2

NGR1 1

SAP49

MATRIN 35

SRP38

SRP

PES4

TIA1

SXL-RRM1 160

SXL-RRM2 246

PAB-RRM2 134

PAB-RRM2
HUD-RRM1 81

HUD-RRM2 167

$\begin{array}{ll}\text { NUC-RRM1 } & 341 \\ \text { NUC-RRM2 } & 326\end{array}$

\section{$\alpha-B$}

RAP 1

105 -----LGDHLVGNYYKFRR--EEDAEKAVIDLNNRWFN--GQPIHAELSPSPVTFREACCR 15 21 -_--VDGVEVPGCGKIFVEFTS--VFDCQKAMQGLTGRKFA--NRVVVTKYCDPD-SYHRRDFW 475 -LEPHLRGNVYVQYOS--EEECQAALSLFNGRWYA--GROLOCEFCPVT-RIKMAICG 313 --NPGRGVFVEYAN--AGDSKAAQKLLTGRMPD--GKFVVATFYPLS-AYKRGYLY 415

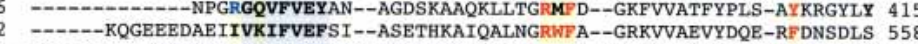
- - - PGAPDDEAVRIFLEFER--VESAIKAVVDLNGRYFG--GRVVKACFYNLD-KFRVLDLA 398 ---DEPNFPVHEAVRIFVQFSR--PEETTKALVDLDGRYFG--GRTVRATFYDEE-KFSKNELA 37 -HPDGVASVSFRD--PEEADYCIQTLDGRWFG--GRQITAQAWDGTTDYQVEETS 359 EPDGVVTVRFSN--NEEAEACVRLMQGRYFD--GRVVEASIYDGKVRFQKSGKH 344 --KGEATVVFKN--NKVALQCCKIMTGRYFD--GQKLLAFISGDENTSSTSDKN 275

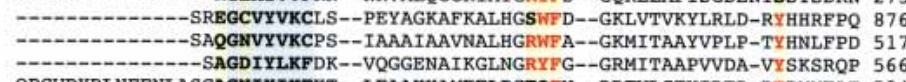
$\begin{array}{lll}-1 & -1\end{array}$

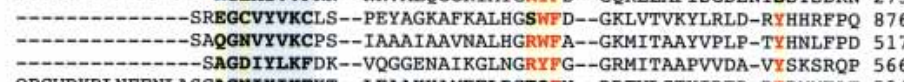
QPGVDYRLNFENLASGAGNIYIKFKT--LEAAKHAMEELPGTQFN--DRTVLCTYIDED-DFDMMEAT 524 -ENGKSTVALVEFRS--VEDAQTALI-RDGKYFG--DHTISVKEAAGITLYVTNFPP 395 -PLTGSSRCFGFVRFGD--EDERRRALIEMSGIWFQ--GRALRVAYATPRNNMMLQLQE 281 -DPDTGNSKGYAFINFAS--FDASDAAIEAMNGQYLC--NRPITVSYAFKKDSKGERHGS 189 -FYTRRPRGFAYVOFED--VRDAEDALHNLDRKWIC--GROIEIOFAOGDRKTPNOMKA 98 TKVX

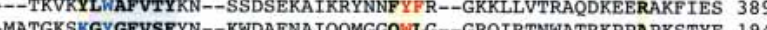

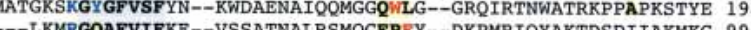
作 作作

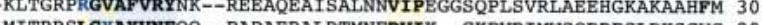
MITRRSLGYAYUNFQQ--PADAERALDTMNFDVIK--GKPVRIMWSQRDPSLRKSGVG 99 --ENGSKGYGFVHFET--QEAAERAIEKMNGMLLN--DRKVFVGRFKSRKEREAELGA 185 -QVTGVSRGVGF IRFDK--RIEAEEAIKGLNGQKPSGATEPITVKFANNPSQKSSQALL 222 -VRTGTNRKF GYVDFES--AEDLEKALE-LTGLKVF--GNEIKLEKPKGRDSKKVRAAR 393 -GKSKGIAYIEFKS--EADAEKNLEEKQGAEID--GRSVSLYYTGEKGGQRQERTG 475
475 -1-KSOAFIEMETREDAMAMVDHCLKKALWO--GRCVKVDLSEKYKKLVIRIPN 581 KITGQSLGYGFVNYID--PKDAEKAINTLNGLRLQ--TKTIKVSYARPSSASIRDANL 134

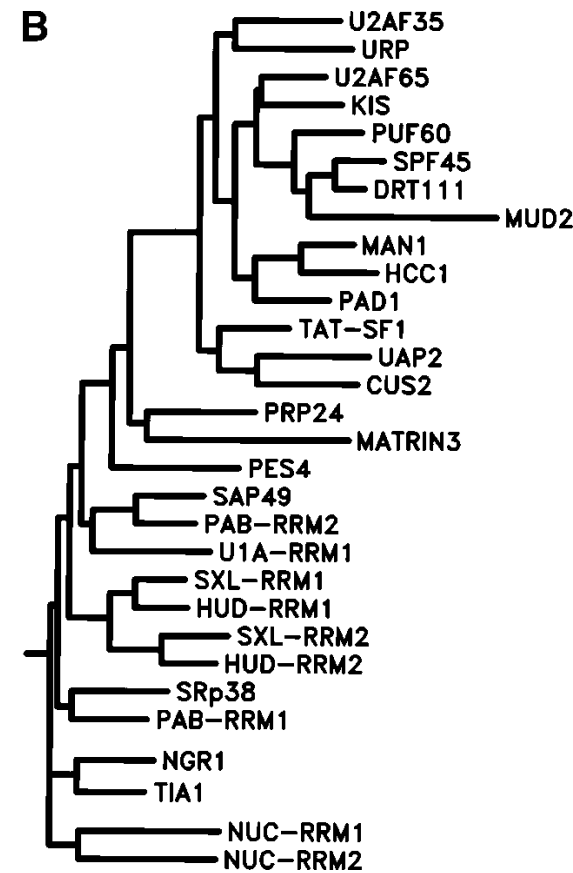

B

Figure 4. Identification of candidate UHM-containing proteins. (A) Structure-based alignment of candidate UHM sequences, U2AF ${ }^{35}$. $\mathrm{UHM}, \mathrm{U} 2 \mathrm{AF}^{65} \mathrm{UHM}_{\text {, }}$ and representative canonical RRMs whose structures in complex with RNA are known. Structures were aligned using the program TOPP from the CCP4 suite (Collaborative Computational Project, no. 4, 1994). Secondary structure elements are indicated above the sequences. The positions of key residues that distinguish UHM from RRM domains are highlighted yellow. Consensus UHM residues including acidic residues and the Arg-X-Phe loop are red. Residues in the RNP-like motifs that match the canonical RRM consensus are blue. $(B)$ Phylogenetic tree of candidate UHM domains.

UHM domains via a similar arrangement of basic and Trp residues. A search for the ligand consensus pattern [RK]-X-[RK]-W, shared by both the SF1 and U2AF ${ }^{65}$ ligands, found $>1000$ matches within the SWISS-PROT database, indicating that predicting protein ligands of candidate UHMs is impractical without further experimental information to identify their functional binding partners. Given that all 12 compelling UHM candidates possess the signature sequences predicted to recognize ligands containing the $[\mathrm{RK}]-\mathrm{X}-[\mathrm{RK}]-\mathrm{W}$ motif, it remains an open question whether each UHM domain specifi- cally recognizes a single target, or could promiscuously interact with the intended ligand of a different UHM in the absence of temporal or spatial regulation. Toward answering this question, the $\mathrm{U}_{2} \mathrm{AF}^{65}$-UHM has been found not to interact with the $\mathrm{N}$ terminus of the $\mathrm{U}_{2} \mathrm{AF}^{65}$-ligand in two-hybrid assays (Tronchere et al. 1997) and pull-down experiments (C. Kielkopf, unpubl.), suggesting that individual UHMs may, indeed, specifically recognize a unique target. By analogy with other modular peptide binding domains (Pawson and Nash 2003), UHM sequences flanking the Trp-binding pocket 
Table 2. Representative homologs of UHM candidates

\begin{tabular}{|c|c|c|c|c|}
\hline $\begin{array}{l}\text { Human } \\
\text { protein }\end{array}$ & $\begin{array}{c}\text { Accession } \\
\text { number }\end{array}$ & Homolog ${ }^{\mathrm{a}}$ & Source organism & $\begin{array}{c}\text { Sequence } \\
\text { identity } \\
(\%)\end{array}$ \\
\hline $\mathrm{U} 2 \mathrm{AF}^{35}$ & Q01081 & $\begin{array}{l}\text { Q9D883 } \\
\text { AAM34646 } \\
\text { AAB17271 } \\
\text { EAA08115 } \\
\text { AAM97101 } \\
\text { CAB55137 }\end{array}$ & $\begin{array}{l}\text { M. musculus } \\
\text { D. rerio } \\
\text { D. melanogaster } \\
\text { A. gambiae } \\
\text { A. thaliana } \\
\text { C. elegans }\end{array}$ & $\begin{array}{r}100 \\
97 \\
82 \\
82 \\
54 \\
66\end{array}$ \\
\hline $\mathrm{U} 2 \mathrm{AF}^{65}$ & P26368 & $\begin{array}{l}\text { P26369 } \\
\text { AAH65869 } \\
\text { A48249 } \\
\text { EAA08228 } \\
\text { E96634 } \\
\text { AAC26982 }\end{array}$ & $\begin{array}{l}\text { M. musculus } \\
\text { D. rerio } \\
\text { D. melanogaster } \\
\text { A. gambiae } \\
\text { A. thaliana } \\
\text { C. elegans }\end{array}$ & $\begin{array}{l}99 \\
85 \\
72 \\
61 \\
42 \\
59\end{array}$ \\
\hline KIS & Q8TAS1 & AAH58732 & M. musculus & 99 \\
\hline PUF60 & AAF05605 & $\begin{array}{l}\text { AAH10601 } \\
\text { CAD61099 } \\
\text { EAA09944 } \\
\text { AAF47501 } \\
\text { AAF60676 }\end{array}$ & $\begin{array}{l}\text { M. musculus } \\
\text { D. rerio } \\
\text { A. gambiae } \\
\text { D. melanogaster } \\
\text { C. elegans }\end{array}$ & $\begin{array}{l}95 \\
76 \\
53 \\
49 \\
48\end{array}$ \\
\hline SPF45 & AAH39322 & $\begin{array}{l}\text { AAC64085 } \\
\text { AAH45473 } \\
\text { EAA15153 } \\
\text { EAA46008 } \\
\text { CAA97799 }\end{array}$ & $\begin{array}{l}\text { M. musculus } \\
\text { D. rerio } \\
\text { A. gambiae } \\
\text { D. melanogaster } \\
\text { C. elegans }\end{array}$ & $\begin{array}{r}100 \\
78 \\
39 \\
36 \\
35\end{array}$ \\
\hline Tat-SF1 & AAB18823 & $\begin{array}{l}\text { AAH37711 } \\
\text { AAH55565 } \\
\text { AAF51719 } \\
\text { EAA10753 } \\
\text { AAK29956 }\end{array}$ & $\begin{array}{l}\text { M. musculus } \\
\text { D. rerio } \\
\text { D. melanogaster } \\
\text { A. gambiae } \\
\text { C. elegans }\end{array}$ & $\begin{array}{r}100 \\
55 \\
45 \\
44 \\
37\end{array}$ \\
\hline HCC1 & Q14498 & $\begin{array}{l}\text { Q8VH51 } \\
\text { AAH44487 } \\
\text { AAF52478 } \\
\text { EAA12873 } \\
\text { AAM97977 } \\
\text { AAM20703 }\end{array}$ & $\begin{array}{l}\text { M. musculus } \\
\text { D. rerio } \\
\text { D. melanogaster } \\
\text { A. gambiae } \\
\text { C. elegans } \\
\text { A. thaliana }\end{array}$ & $\begin{array}{l}99 \\
79 \\
61 \\
53 \\
47 \\
42\end{array}$ \\
\hline MAN1 & AAF73293 & Q9WU40 & M. musculus & 70 \\
\hline
\end{tabular}

aCandidates identified from Homo sapiens, Mus musculus, Danio rerio, Anopheles gambiae, Drosophila melanogaster, Arabidopsis thaliana, and Caenorhabditis elegans, based on similar domain structure and $>35 \%$ sequence identity in matching regions identified by the PSI-BLAST program (Altschul et al. 1997).

bequence identity between the human candidate and the homolog from the indicated source organism.

may ensure specific and directional interactions (N-to-C orientation) with the ligand.

In support of this analogy, structure-based modeling suggests that variation of the central $\mathbf{X}$ residue in the UHM Arg-X-Phe loop may provide one mechanism for UHM recognition of diverse C-terminal ligand sequences. Several of the UHM candidates (hURP, PUF60, Tat-SF1, and HCC1) share a Trp residue within the Arg$\mathbf{X}$-Phe loop that is essential in the $\mathrm{U}_{2} \mathrm{AF}^{35}$-UHM for specific recognition of $\mathrm{C}$-terminal $\mathrm{U}_{2} \mathrm{AF}^{65}$-ligand-Pro residues (Kielkopf et al. 2001). Other UHM sequences vary from similar Arg-Tyr-Phe motifs (SPF45, DRT111, UAP2, CUS2, and PAD1) to divergent Lys $\left(\mathrm{U}_{2} \mathrm{AF}^{65}\right)$ and Met (KIS) residues. Besides recognizing the ligand $\mathrm{C}$ terminus via the Arg-X-Phe loop, distinct $U 2 A^{-65}-U H M$ or $\mathrm{U}_{2} \mathrm{AF}^{35} \mathrm{U} \mathrm{UHM}$ residues make specific contacts with $\mathrm{N}$ terminal ligand residues. In particular, the bulky $\mathrm{U}_{2} \mathrm{AF}^{65}$-ligand Tyr 91 stacks against unique $\mathrm{U}_{2} \mathrm{AF}^{35}$ aromatic residues (Tyr 52 and Phe 81), and forms a specific hydrogen-bond with His 77 of the U2AF ${ }^{35}$-UHM (Kielkopf et al. 2001). Similar or identical residues in the URP-UHM (Phe 206, Phe 239, and Gln 235) suggest that a bulky, hydrophobic residue preceding the consensus ligand-Trp would be recognized in an analogous manner, consistent with an interaction between hURP and $\mathrm{U}_{2} \mathrm{AF}^{65}$ in pull-down and yeast two-hybrid assays (Tronchere et al. 1997). The smaller size of the corresponding $\mathrm{U}_{2} \mathrm{AF}^{65}$-UHM residues (Ile 398 and Val 384) would leave the hydrophobic side chain of a ligand-Tyr in an unfavorable, solvent-exposed environment (Selenko et al. 2003). Considering the variety of cellular roles played by UHM candidates and the consequent requirement to recognize diverse protein ligands, it will be important to determine whether variation in the positions corresponding to $\mathrm{U}_{2} \mathrm{AF}^{35}$ Tyr 52, Phe 81, and His 77, and the central position of the Arg-X-Phe loop enables recognition of distinct ligand sequences by UHM domains.

In addition to recognizing short peptide ligands, UHM domains can self-associate to form protein homodimers. For example, the PUF60-UHM domain interacts with itself in two-hybrid assays (Poleev et al. 2000) and forms SDS-resistant homodimers during electrophoresis (PageMcCaw et al. 1999). The U2AF ${ }^{35}$-UHM has been shown to form weak homodimers by gel filtration, analytical ultracentrifugation, dynamic light scattering (Kielkopf et al. 2001), and two-hybrid assays (Wentz-Hunter and Potashkin 1996), whereas homodimers of the U2AF ${ }^{65}-\mathrm{UHM}$ have not been observed (Tronchere et al. 1997). Homo- or heterotypic oligomerizations also have been observed for classical protein-protein interaction domains, with several different effects on ligand recognition. For example, the nNOS-PDZ/syntrophin heterodimer prohibits peptide recognition (Hillier et al. 1999), whereas GRIP or Shank PDZ homodimers leave the peptide-binding pockets free (Im et al. 2003a,b) and the Eps8-SH3 homodimer alters the ligand specificity (Kishan et al. 1997). Although a U2AF ${ }^{35}$-UHM homodimer can be modeled with the solvent exposed Arg-Trp-Phe loop binding to the Trp-binding site on a second UHM domain, alternative interfaces are possible that would allow the oligomer to simultaneously recognize peptide ligands, as observed for established protein-protein interaction domains.

\section{Do UHM domains recognize RNA?}

Modeling of the U2AF-UHM/ligand structures with RNA has revealed that peptide binding to the helical surface of the RRM-like fold is not predicted to physi- 
Table 3. Function of human UHM candidates and their potential disease relevance

\begin{tabular}{|c|c|c|c|c|c|}
\hline $\begin{array}{l}\text { UHM } \\
\text { candidate }\end{array}$ & Full Name & Domain Organization & Function & $\begin{array}{l}\text { Relevance to human } \\
\text { disease }\end{array}$ & References \\
\hline URP & $\begin{array}{l}\text { U2AF-Related } \\
\text { Protein }\end{array}$ & Zn UHM Zn $=482$ & $\begin{array}{l}\text { Involved in pre-mRNA } \\
\text { splicing. }\end{array}$ & $\begin{array}{l}\text { Altered methylation of } \\
\text { U2AF1-RS1 is associated } \\
\text { with developmental } \\
\text { defects. }\end{array}$ & $\begin{array}{l}\text { (Kitagawa et al. } \\
\text { 1995; Tronchere } \\
\text { et al. 1997; Dean } \\
\text { et al. 1998). }\end{array}$ \\
\hline KIS & $\begin{array}{l}\text { Kinase Interacting } \\
\text { with Stathmin }\end{array}$ & S/T Kinase UHM 419 & $\begin{array}{l}\text { Phosphorylates a variety } \\
\text { of proteins in vitro } \\
\text { including the cyclin- } \\
\text { dependent kinase inhibitor } \\
\text { p } 27^{\text {Kipl. }}\end{array}$ & $\begin{array}{l}\text { KIS mRNA levels are } \\
\text { misregulated in } \\
\text { neurological tumors } \\
\text { associated with } \\
\text { neurofibromatosis type I } \\
\text { (NF1). }\end{array}$ & $\begin{array}{l}\text { (Maucuer et al. } \\
\text { 1995; Maucuer et } \\
\text { al. 2000; Boehm } \\
\text { et al. 2002; } \\
\text { Bieche et al. } \\
\text { 2003). }\end{array}$ \\
\hline PUF60 & $\begin{array}{l}\text { Poly-Uridine } \\
\text { Factor 60KD }\end{array}$ & RRM RRM UHM 559 & $\begin{array}{l}\text { Involved in pre-mRNA } \\
\text { splicing; an alternatively } \\
\text { spliced form, FBP- } \\
\text { Interacting-Protein (FIR), } \\
\text { blocks activator- } \\
\text { dependent } c \text {-myc } \\
\text { transcription. }\end{array}$ & $\begin{array}{l}\text { The Drosophila } \\
\text { homologue regulates } \\
\text { splicing of certain ovarian } \\
\text { genes during } \\
\text { development; cells from } \\
\text { xeroderma pigmentosa } \\
\text { (XP)B and XPD patients } \\
\text { are defective in FIR } \\
\text { repression. }\end{array}$ & $\begin{array}{l}\text { (Page-McCaw et } \\
\text { al. 1999; Liu et } \\
\text { al. 2000; Poleev } \\
\text { et al. 2000; Liu et } \\
\text { al. 2001; Van } \\
\text { Buskirk and } \\
\text { Schupbach 2002; } \\
\text { Zhou et al. 2002). }\end{array}$ \\
\hline SPF45 & $\begin{array}{l}\text { Splicing Factor } \\
45 \mathrm{KD}\end{array}$ & - G-patch-UHM 405 & $\begin{array}{l}\text { Involved in pre-mRNA } \\
\text { splicing; putative } \\
\text { homologues from } \\
\text { Arabidopsis thaliana } \\
\text { (DRT111) and } \\
\text { Toxoplasma gondii } \\
\text { suggest a second function } \\
\text { in DNA repair. }\end{array}$ & $\begin{array}{l}\text { SPF45 is over-expressed } \\
\text { in a variety of human } \\
\text { cancers. }\end{array}$ & $\begin{array}{l}\text { (Pang et al. 1993; } \\
\text { Neubauer et al. } \\
\text { 1998; Dendouga } \\
\text { et al. 2002; } \\
\text { Lallena et al. } \\
\text { 2002; Sampath et } \\
\text { al. 2003). }\end{array}$ \\
\hline TAT-SF1 & $\begin{array}{l}\text { Tat Stimulatory } \\
\text { Factor } 1\end{array}$ & G-patch UHM 405 & $\begin{array}{l}\text { Stimulates transcription } \\
\text { elongation; human and } \\
\text { putative yeast homologues } \\
\text { (CUS2, UAP2) associate } \\
\text { with splicing factors. }\end{array}$ & $\begin{array}{l}\text { Involved in HIV-1 } \\
\text { pathogenesis by } \\
\text { stimulating Tat-dependent } \\
\text { transcription. }\end{array}$ & $\begin{array}{l}\text { (Zhou and Sharp } \\
\text { 1996; McKinney } \\
\text { et al. 1997; Li } \\
\text { and Green 1998; } \\
\text { Yan et al. 1998; } \\
\text { Fong and Zhou } \\
\text { 2001). }\end{array}$ \\
\hline MAN1 & MAN antigen 1 & LEM $=$ TM-TM-UHM $=911$ & $\begin{array}{l}\text { Xenopus laevis } \\
\text { homologues regulate bone } \\
\text { morphogenetic protein } \\
\text { (BMP) signaling. }\end{array}$ & $\begin{array}{l}\text { Disruption of BMP/TGF- } \beta \\
\text { signaling pathways } \\
\text { mediated by MAN1 are } \\
\text { associated with vascular } \\
\text { diseases and cancers. }\end{array}$ & $\begin{array}{l}\text { (Lin et al. 2000; } \\
\text { Osada et al. 2003; } \\
\text { Raju et al. 2003; } \\
\text { Waite and Eng } \\
\text { 2003). }\end{array}$ \\
\hline $\mathrm{HCCl}$ & $\begin{array}{l}\text { Hepatocellular } \\
\text { Carcinoma } 1\end{array}$ & RS RRM RRM UHM 554 & $\begin{array}{l}\text { Involved in pre-mRNA } \\
\text { splicing; mouse } \\
\text { homologue is a } \\
\text { transcriptional coactivator. }\end{array}$ & $\begin{array}{l}\text { Originally identified as a } \\
\text { nuclear autoantigen from a } \\
\text { patient with hepatocellular } \\
\text { carcinoma. }\end{array}$ & $\begin{array}{l}\text { (Imai et al. 1993; } \\
\text { Kuldau et al. } \\
\text { 1998; Jung et al. } \\
\text { 2002; Auboeuf et } \\
\text { al. 2004) }\end{array}$ \\
\hline
\end{tabular}

Domains are annotated according to CDD (Marchler-Bauer et al. 2002). (RS) Arg-Ser rich; (Zn) zinc binding; (S/T kinase) Ser/Thr phosphokinase; (G-patch) Gly rich; (acidic) Glu/Asp rich; (TM) transmembrane region; (LEM) LAP2-Emerin-Man1 homology.

cally interfere with putative RNA interactions on the opposite $\beta$-sheet face (Kielkopf et al. 2001; Selenko et al. 2003). Although the U2AF ${ }^{35}$-UHM/U2AF ${ }^{65}$-ligand complex binds RNA weakly $(\mathrm{Kd}>6 \mu \mathrm{M})$, accessory protein factors and adjacent domains in the full-length U2AF ${ }^{35}$ sequence (e.g., flanking zinc fingers and an RS domain) are required to assist the weak interaction (Rudner et al. 1998a; J. Valcarcel, pers. comm.). Likewise, the U2AF ${ }^{65}$. UHM domain is not required for Py-tract recognition (Banerjee et al. 2003), and does not appear to interact with RNA (Selenko et al. 2003). These results indicate that UHM domains are not likely to be involved in RNA interactions.

Instead, the UHM family has evolved sequence characteristics that have no benefit for RNA binding, while optimizing the interaction with peptide ligands. In most canonical RRM-RNA structures, conserved aromatic Phe/Tyr residues at the third RNP1 position or second RNP2 position stack with RNA bases or sugars, and a basic Arg/Lys residue at the first position of the RNP1 motif frequently forms a salt bridge with the phosphate backbone (Fig. 5A; Oubridge et al. 1994; Price et al. 1998; Deo et al. 1999; Handa et al. 1999; Allain et al. 2000; Wang and Tanaka Hall 2001). In contrast, the corresponding U2AF ${ }^{35}$-UHM (Fig. 5B) and U2 $\mathrm{AF}^{65}$-UHM (Fig. 5C) residues are replaced with aliphatic substitutions that are not predicted to interact favorably with RNA. Moreover, UHMs display unexpectedly low isoelectric points for optimal binding of basic peptides.

In addition to poor conservation of RNP-like motifs and overall negative charge, RNA binding by the $\mathrm{U}_{2} \mathrm{AF}^{65}$-UHM structure is further inhibited by a C-ter- 
Kielkopf et al.

A
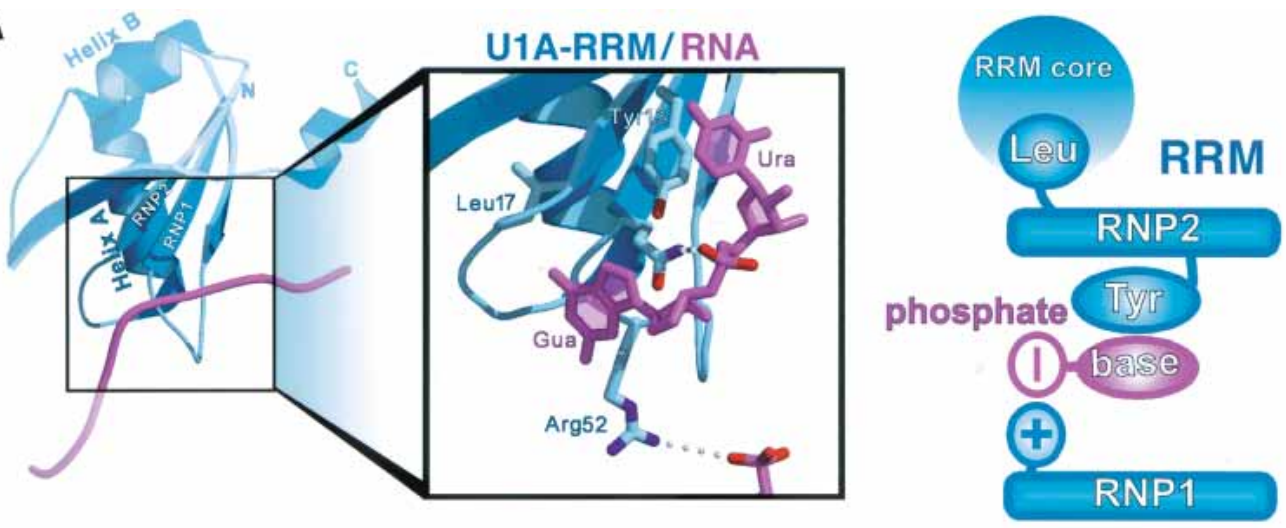

B

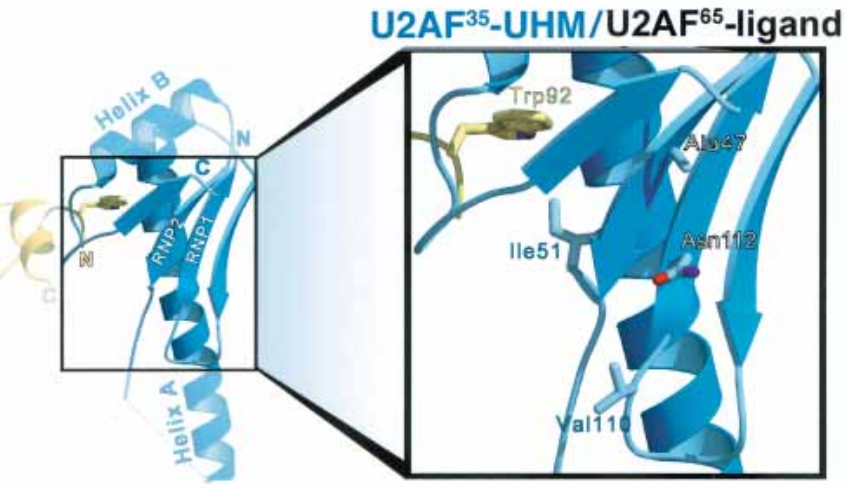

C
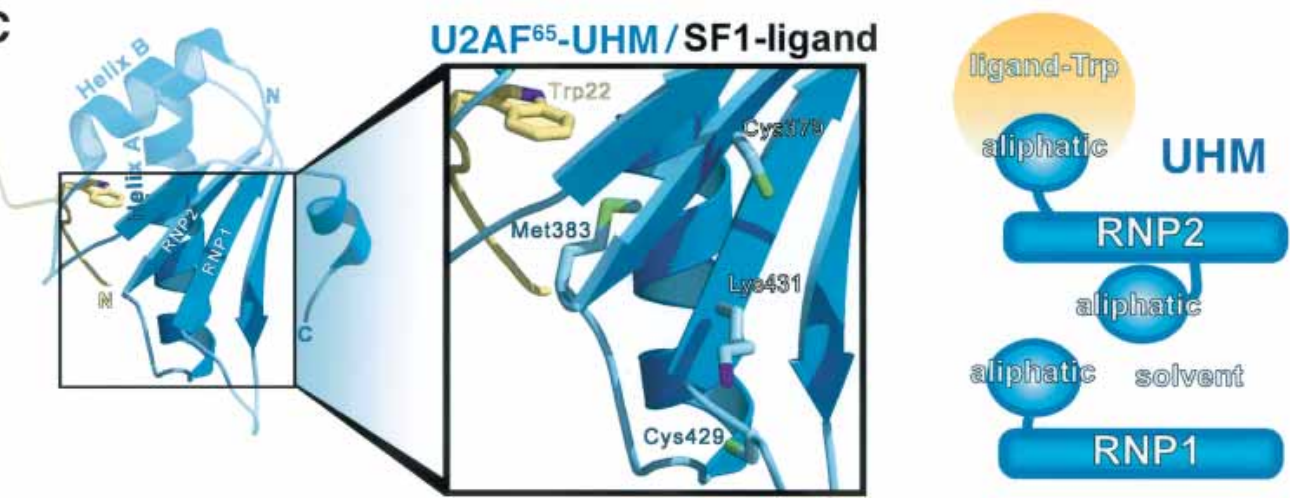

Figure 5. RNA recognition by an RRM domain compared with the U2AF-UHM domains. The UHM or RRM domains are shown in blue, protein ligands are yellow, and RNA ligands are purple. (A) The U1A-RRM recognizing an RNA oligonucleotide. The RNP1-Arg recognizes the RNA phosphates, a nucleotide base stacks on RNP2-Tyr, and RNP2-Leu is folded in the hydrophobic core. (B) The $\mathrm{U}_{2} \mathrm{AF}^{35}$-UHM/U2AF ${ }^{65}$-ligand complex (PDB code $1 \mathrm{JMT}$ ) rotated $180^{\circ}$ about the $Y$-axis with respect to Figure 3 to show the putative RNA interaction surface. $(C)$ Similar view of the U2AF ${ }^{65}$-UHM/SF1-ligand structure (PDB code 1O0P). The RNP2-Ile packs with the ligand-Trp. The small aliphatic residues in the RNP-like motifs are predicted to be unable to form favorable RNA interactions. Schematic representation of RNP residues that differ between UHMs compared with canonical RRMs is shown to the right.

minal $\alpha$-helix that forms a tight hydrophobic interface with the putative RNA-binding surface of the RRM-like fold (Selenko et al. 2003). In contrast, the C-terminal extensions of canonical RRMs more often strengthen rather than inhibit RNA binding. For example, the Cterminal helical extension of the N-terminal U1A-RRM not only contributes to RNA binding (Oubridge et al. 1994; Zeng and Hall 1997) but also mediates dimer formation for recognition of tandem RNA elements (Klein Gunnewiek et al. 2000; Varani et al. 2000). Based on the
U2AF ${ }^{65}$-UHM structure, Phe 433 in the RNP1-like motif and Tyr 463 within the preceding turn interact with Tyr 469, Phe 474, and Trp 475 in the C-terminal $\alpha$-helix (Selenko et al. 2003). Although counterparts of Phe 474 and Trp 475 are absent among the UHM candidates, aromatic residues at positions corresponding to Phe 433, Tyr 463, and Tyr 469 are observed for the UHM domains of KIS, PUF60, SPF45, and HCC1. This raises the possibility that some of the UHM candidates may have a hydrophobic C-terminal extension that may either inter- 
fere with RNA binding as for the $\mathrm{U}_{2} \mathrm{AF}^{65}-\mathrm{UHM}$, or contribute to homodimer formation in a manner similar to U1A.

\section{Conclusions}

The canonical RRM domain was a relatively late evolutionary addition to the array of RNA-binding folds that emerged in response to the needs of complex pre-mRNA processing pathways (Anantharaman et al. 2002). As processes that were originally based on the RNA world became progressively more regulated and reliant on protein interactions, the RRM fold further developed specialized sequence characteristics for protein recognition to form the UHM subfamily. These UHM signature sequences included divergent residues in the RNP-like motifs, an Arg-X-Phe loop sequence, and key acidic residues that collectively recognized the Trp residue and positive charge of the protein ligand. Convincing UHM candidates have been discovered in association with a variety of fundamental cellular processes, ranging from premRNA splicing to transcription, DNA repair, and signal transduction. The large number of proteins that share the signature protein-protein interaction residues of UHM domains supports the proposal that the U2AFUHMs represent a novel family of modular protein interaction domains.

Because protein interaction domains are attractive modules for communication among a network of pathways, the UHM domain may be an evolutionary extension of RRMs that couples pre-mRNA processing with other nuclear processes. Protein recognition by so-called RNA-binding domains is an emerging theme in molecular recognition. An early example of RRM-protein interactions was observed in the structure of $\mathrm{U}^{2} \mathrm{~B}^{\prime \prime} / \mathrm{U}^{2} \mathrm{~A}^{\prime}$, in which the $\alpha$-helical surface of the U2B"-RRM interacts with the U2A' leucine-rich repeat motif (Price et al. 1998). Several recent structures of the $\beta$-sheet surfaces of heterodimeric RRM domains interacting with $\alpha$-helical protein ligands have revealed a second mode of RRMprotein recognition distinct from that of UHM/protein complexes (Fribourg et al. 2003; Lau et al. 2003; Shi and $\mathrm{Xu}$ 2003; Kadlec et al. 2004). In addition to distinguishing protein recognition domains within the RRM family, a growing list of fold families such as the Sterile $\alpha$-Motif (SAM; Kim and Bowie 2003), LEM (Cai et al. 2001; Laguri et al. 2001), Pumilio/HEAT-repeat domains (Wang et al. 2002), and zinc fingers (Morgan et al. 1997) have been found to bind either nucleic acids or protein ligands through slight variations of a common scaffold. Furthermore, RS domains have been shown to contact the premRNA during splicing (Valcarcel et al. 1996; Shen et al. 2004), and have also been reported to mediate proteinprotein interactions (Wu and Maniatis 1993). Because a major goal of the "postgenomic" era is the ability to predict protein functions even in the absence of corroborating experimental results (Thornton et al. 2000), it will be essential to compile a lexicon of signature sequences, such as those that distinguish UHMs from canonical
RRMs, for other fold families whose members play diverse functional roles.

\section{Acknowledgments}

We thank S. Evans for editorial assistance, and J. Bender, M. Matunis, M. Swenson, and J. Wedekind for careful reading of the manuscript. Funding for C.L.K. is provided by the Johns Hopkins University Center for AIDS Research grant \#P30 AI42855.

\section{References}

Abovich, N., Liao, X.C., and Rosbash, M. 1994. The yeast MUD2 protein: An interaction with PRP11 defines a bridge between commitment complexes and U2 snRNP addition. Genes \& Dev. 8: 843-854.

Adam, S.A., Nakagawa, T., Swanson, M.S., Woodruff, T.K., and Dreyfuss, G. 1986. mRNA polyadenylate-binding protein: Gene isolation and sequencing and identification of a ribonucleoprotein consensus sequence. Mol. Cell. Biol. 6: 29322943.

Allain, F.H., Bouvet, P., Dieckmann, T., and Feigon, J. 2000. Molecular basis of sequence-specific recognition of pre-ribosomal RNA by nucleolin. EMBO I. 19: 6870-6881.

Altschul, S.F., Madden, T.L., Schaffer, A.A., Zhang, J., Zhang, Z., Miller, W., and Lipman, D.J. 1997. Gapped BLAST and PSI-BLAST: A new generation of protein database search programs. Nucleic Acids Res. 25: 3389-3402.

Anantharaman, V., Koonin, E.V., and Aravind, L. 2002. Comparative genomics and evolution of proteins involved in RNA metabolism. Nucleic Acids Res. 30: 1427-1464.

Auboeuf, D., Honig, A., Berget, S.M., and O'Malley, B.W. 2002. Coordinate regulation of transcription and splicing by steroid receptor coregulators. Science 298: 416-419.

Auboeuf, D., Dowhan, D.H., Kang, Y.K., Larkin, K., Lee, J.W., Berget, S.M., and O'Malley, B.W. 2004. Differential recruitment of nuclear receptor coactivators may determine alternative RNA splice site choice in target genes. Proc. Natl. Acad. Sci. 101: 2270-2274.

Banerjee, H., Rahn, A., Davis, W., and Singh, R. 2003. Sex lethal and U2 small nuclear ribonucleoprotein auxiliary factor $\left(\mathrm{U}_{2} \mathrm{AF}^{65}\right)$ recognize polypyrimidine tracts using multiple modes of binding. RNA 9: 88-99.

Banerjee, H., Rahn, A., Gawande, B., Guth, S., Valcarcel, J., and Singh, R. 2004. The conserved RNA recognition motif 3 of $\mathrm{U} 2$ snRNA auxiliary factor $\left(\mathrm{U}_{2} \mathrm{AF}^{65}\right)$ is essential in vivo but dispensable for activity in vitro. RNA 10: 240-253.

Bennett, M., Michaud, S., Kingston, J., and Reed, R. 1992. Protein components specifically associated with prespliceosome and spliceosome complexes. Genes \& Dev. 6: 19862000.

Berglund, J.A., Abovich, N., and Rosbash, M. 1998. A cooperative interaction between U2AF65 and mBBP/SF1 facilitates branchpoint region recognition. Genes \& Dev. 12: 858-867.

Bieche, I., Manceau, V., Curmi, P.A., Laurendeau, I., Lachkar, S., Leroy, K., Vidaud, D., Sobel, A., and Maucuer, A. 2003. Quantitative RT-PCR reveals a ubiquitous but preferentially neural expression of the KIS gene in rat and human. Brain Res. Mol. Brain Res. 114: 55-64.

Birney, E., Kumar, S., and Krainer, A.R. 1993. Analysis of the RNA-recognition motif and RS and RGG domains: Conservation in metazoan pre-mRNA splicing factors. Nucleic Acids Res. 21: 5803-5816.

Boehm, M., Yoshimoto, T., Crook, M.F., Nallamshetty, S., 
True, A., Nabel, G.J., and Nabel, E.G. 2002. A growth factordependent nuclear kinase phosphorylates $\mathrm{p} 27^{\mathrm{Kip} 1}$ and regulates cell cycle progression. EMBO J. 21: 3390-3401.

Brazma, A., Jonassen, I., Ukkonen, E., and Vilo, J. 1996. Discovering patterns and subfamilies in biosequences. Proc. Int. Conf. Intell. Syst. Mol. Biol. 4: 34-43.

Brow, D.A. 2002. Allosteric cascade of spliceosome activation. Annu. Rev. Genet. 36: 333-360.

Burd, C.G. and Dreyfuss, G. 1994. Conserved structures and diversity of functions of RNA-binding proteins. Science 265: 615-621.

Cai, M., Huang, Y., Ghirlando, R., Wilson, K.L., Craigie, R., and Clore, G.M. 2001. Solution structure of the constant region of nuclear envelope protein LAP2 reveals two LEM-domain structures: One binds BAF and the other binds DNA. EMBO J. 20: 4399-4407.

Chiara, M.D., Palandjian, L., Feld Kramer, R., and Reed, R. 1997. Evidence that U5 snRNP recognizes the $3^{\prime}$ splice site for catalytic step II in mammals. EMBO J. 16: 4746-4759.

Collaborative Computational Project, number 4. 1994. The CCP4 suite: Programs for protein crystallography. Acta Crystallogr. D50: 760-763.

Dean, W., Bowden, L., Aitchison, A., Klose, J., Moore, T., Meneses, J.J., Reik, W., and Feil, R. 1998. Altered imprinted gene methylation and expression in completely ES cell-derived mouse fetuses: Association with aberrant phenotypes. Development 125: 2273-2282.

Dendouga, N., Callebaut, I., and Tomavo, S. 2002. A novel DNA repair enzyme containing RNA recognition, G-patch and specific splicing factor 45-like motifs in the protozoan parasite Toxoplasma gondii. Eur. J. Biochem. 269: 3393-3401.

Deo, R.C., Bonanno, J.B., Sonenberg, N., and Burley, S.K. 1999. Recognition of polyadenylate RNA by the poly(A)-binding protein. Cell 98: 835-845.

Dreyfuss, G., Swanson, M.S., and Pinol-Roma, S. 1988. Heterogeneous nuclear ribonucleoprotein particles and the pathway of mRNA formation. Trends Biochem. Sci. 13: 86-91.

Fong, Y.W. and Zhou, Q. 2001. Stimulatory effect of splicing factors on transcriptional elongation. Nature 414:929933.

Fribourg, S., Gatfield, D., Izaurralde, E., and Conti, E. 2003. A novel mode of RBD-protein recognition in the Y14-Mago complex. Nat. Struct. Biol. 10: 433-439.

Gattiker, A., Gasteiger, E., and Bairoch, A. 2002. ScanProsite: A reference implementation of a PROSITE scanning tool. Appl. Bioinformatics 1: 107-108.

Golling, G., Amsterdam, A., Sun, Z., Antonelli, M., Maldonado, E., Chen, W., Burgess, S., Haldi, M., Artzt, K., Farrington, S., et al. 2002. Insertional mutagenesis in zebrafish rapidly identifies genes essential for early vertebrate development. Nat. Genet. 31: 135-140.

Gozani, O., Potashkin, J., and Reed, R. 1998. A potential role for U2AF-SAP155 interactions in recruiting U2 snRNP to the branch site. Mol. Cell. Biol. 18: 4752-4760.

Habara, Y., Urushiyama, S., Tani, T., and Ohshima, Y. 1998. The fission yeast prp $10^{+}$gene involved in pre-mRNA splicing encodes a homologue of highly conserved splicing factor, SAP155. Nucleic Acids Res. 26: 5662-5669.

Handa, N., Nureki, O., Kurimoto, K., Kim, I., Sakamoto, H., Shimura, Y., Muto, Y., and Yokoyama, S. 1999. Structural basis for recognition of the tra mRNA precursor by the Sexlethal protein. Nature 398: 579-585.

Hillier, B.J., Christopherson, K.S., Prehoda, K.E., Bredt, D.S., and Lim, W.A. 1999. Unexpected modes of PDZ domain scaffolding revealed by structure of nNOS-syntrophin complex. Science 284: 812-815.
Hoffman, D.W., Query, C.C., Golden, B.L., White, S.W., and Keene, J.D. 1991. RNA-binding domain of the A protein component of the U1 small nuclear ribonucleoprotein analyzed by NMR spectroscopy is structurally similar to ribosomal proteins. Proc. Natl. Acad. Sci. 88: 24952499.

Im, Y.J., Lee, J.H., Park, S.H., Park, S.J., Rho, S.H., Kang, G.B., Kim, E., and Eom, S.H. 2003a. Crystal structure of the Shank PDZ-ligand complex reveals a class I PDZ interaction and a novel PDZ-PDZ dimerization. I. Biol. Chem. 278: 4809948104.

Im, Y.J., Park, S.H., Rho, S.H., Lee, J.H., Kang, G.B., Sheng, M., Kim, E., and Eom, S.H. 2003b. Crystal structure of GRIP1 PDZ6-peptide complex reveals the structural basis for class II PDZ target recognition and PDZ domain-mediated multimerization. J. Biol. Chem. 278: 8501-8507.

Imai, H., Chan, E.K., Kiyosawa, K., Fu, X.D., and Tan, E.M. 1993. Novel nuclear autoantigen with splicing factor motifs identified with antibody from hepatocellular carcinoma. $J$. Clin. Invest. 92: 2419-2426.

Jung, D.J., Na, S.Y., Na, D.S., and Lee, J.W. 2002. Molecular cloning and characterization of CAPER, a novel coactivator of activating protein-1 and estrogen receptors. J. Biol. Chem. 277: 1229-1234.

Kadlec, J., Izaurralde, E., and Cusack, S. 2004. The structural basis for the interaction between nonsense-mediated mRNA decay factors UPF2 and UPF3. Nat. Struct. Mol. Biol. 11: 330-337.

Kanaar, R., Roche, S.E., Beall, E.L., Green, M.R., and Rio, D.C. 1993. The conserved pre-mRNA splicing factor U2AF from Drosophila: Requirement for viability. Science 262: 569-573.

Kielkopf, C.L., Rodionova, N.A., Green, M.R., and Burley, S.K. 2001. A novel peptide recognition mode revealed by the $\mathrm{X}$ ray structure of a core $\mathrm{U} 2 \mathrm{AF}^{35} / \mathrm{U} 2 \mathrm{AF}^{65}$ heterodimer. Cell 106: 595-605.

Kim, C.A. and Bowie, J.U. 2003. SAM domains: Uniform structure, diversity of function. Trends Biochem. Sci. 28: 625628.

Kishan, K.V., Scita, G., Wong, W.T., Di Fiore, P.P., and Newcomer, M.E. 1997. The SH3 domain of Eps8 exists as a novel intertwined dimer. Nat. Struct. Biol. 4: 739-743.

Kitagawa, K., Wang, X., Hatada, I., Yamaoka, T., Nojima, H., Inazawa, J., Abe, T., Mitsuya, K., Oshimura, M., Murata, A., et al. 1995. Isolation and mapping of human homologues of an imprinted mouse gene U2AF1-RS1. Genomics 30: 257263.

Klein Gunnewiek, J.M., Hussein, R.I., van Aarssen, Y., Palacios, D., de Jong, R., van Venrooij, W.J., and Gunderson, S.I. 2000. Fourteen residues of the U1 snRNP-specific U1A protein are required for homodimerization, cooperative RNA binding, and inhibition of polyadenylation. Mol. Cell. Biol. 20: 22092217.

Kramer, A. and Utans, U. 1991. Three protein factors (SF1, SF3 and U2AF) function in pre-splicing complex formation in addition to snRNPs. EMBO T. 10: 1503-1509.

Kuldau, G.A., Raju, N.B., and Glass, N.L. 1998. Repeat-induced point mutations in PAD1, a putative RNA splicing factor from Neurospora crassa, confer dominant lethal effects on ascus development. Fungal Genet. Biol. 23: 169-180.

Laguri, C., Gilquin, B., Wolff, N., Romi-Lebrun, R., Courchay, K., Callebaut, I., Worman, H.J., and Zinn-Justin, S. 2001. Structural characterization of the LEM motif common to three human inner nuclear membrane proteins. Structure (Camb) 9: 503-511.

Lahiri, D.K. and Thomas, J.O. 1986. A cDNA clone of the 
hnRNP C proteins and its homology with the singlestranded DNA binding protein UP2. Nucleic Acids Res. 14: 4077-4094.

Lallena, M.J., Chalmers, K.J., Llamazares, S., Lamond, A.I., and Valcarcel, J. 2002. Splicing regulation at the second catalytic step by Sex-lethal involves $3^{\prime}$ splice site recognition by SPF45. Cell 109: 285-296.

Lau, C.K., Diem, M.D., Dreyfuss, G., and Van Duyne, G.D. 2003. Structure of the Y14-Magoh core of the exon junction complex. Curr. Biol. 13: 933-941.

Letunic, I., Copley, R.R., Schmidt, S., Ciccarelli, F.D., Doerks, T., Schultz, J., Ponting, C.P., and Bork, P. 2004. SMART 4.0: Towards genomic data integration. Nucleic Acids Res. 32: D142-D144.

Li, X.Y. and Green, M.R. 1998. The HIV-1 Tat cellular coactivator Tat-SF1 is a general transcription elongation factor. Genes \& Dev. 12: 2992-2996.

Lin, F., Blake, D.L., Callebaut, I., Skerjanc, I.S., Holmer, L., McBurney, M.W., Paulin-Levasseur, M., and Worman, H.J. 2000. MAN1, an inner nuclear membrane protein that shares the LEM domain with lamina-associated polypeptide 2 and emerin. J. Biol. Chem. 275: 4840-4847.

Liu, J., He, L., Collins, I., Ge, H., Libutti, D., Li, J., Egly, J.M., and Levens, D. 2000. The FBP interacting repressor targets TFIIH to inhibit activated transcription. Mol. Cell 5: 331-341.

Liu, J., Akoulitchev, S., Weber, A., Ge, H., Chuikov, S., Libutti, D., Wang, X.W., Conaway, J.W., Harris, C.C., Conaway, R.C., et al. 2001. Defective interplay of activators and repressors with TFIH in xeroderma pigmentosum. Cell 104: 353 363.

Marchler-Bauer, A., Panchenko, A.R., Shoemaker, B.A., Thiessen, P.A., Geer, L.Y., and Bryant, S.H. 2002. CDD: A database of conserved domain alignments with links to domain three-dimensional structure. Nucleic Acids Res. 30: 281283.

Maucuer, A., Camonis, J.H., and Sobel, A. 1995. Stathmin interaction with a putative kinase and coiled-coil-forming protein domains. Proc. Natl. Acad. Sci. 92: 3100-3104.

Maucuer, A., Le Caer, J.P., Manceau, V., and Sobel, A. 2000. Specific Ser-Pro phosphorylation by the RNA-recognition motif containing kinase KIS. Eur. J. Biochem. 267: 44564464.

McKinney, R., Wentz-Hunter, K., Schmidt, H., and Potashkin, J. 1997. Molecular characterization of a novel fission yeast gene spUAP2 that interacts with the splicing factor spU2AF ${ }^{59}$. Curr. Genet. 32: 323-330.

Merendino, L., Guth, S., Bilbao, D., Martinez, C., and Valcarcel, J. 1999. Inhibition of msl-2 splicing by Sex-lethal reveals interaction between $\mathrm{U}_{2} \mathrm{AF}^{35}$ and the $3^{\prime}$ splice site AG. $\mathrm{Na}$ ture 402: 838-841.

Morgan, B., Sun, L., Avitahl, N., Andrikopoulos, K., Ikeda, T., Gonzales, E., Wu, P., Neben, S., and Georgopoulos, K. 1997. Aiolos, a lymphoid restricted transcription factor that interacts with Ikaros to regulate lymphocyte differentiation. EMBO J. 16: 2004-2013.

Nagai, K., Oubridge, C., Jessen, T.H., Li, J., and Evans, P.R. 1990. Crystal structure of the RNA-binding domain of the U1 small nuclear ribonucleoprotein A. Nature 348: 515-520.

Nelson, K. and Green, M. 1989. Mammalian U2 snRNP has a sequence-specific RNA-binding activity. Genes \& Dev. 3: 1562-1571.

Neubauer, G., King, A., Rappsilber, J., Calvio, C., Watson, M., Ajuh, P., Sleeman, J., Lamond, A., and Mann, M. 1998. Mass spectrometry and EST-database searching allows characterization of the multi-protein spliceosome complex. Nat. Genet. 20: 46-50.
Osada, S., Ohmori, S.Y., and Taira, M. 2003. XMAN1, an inner nuclear membrane protein, antagonizes BMP signaling by interacting with Smad1 in Xenopus embryos. Development 130: $1783-1794$.

Oubridge, C., Ito, N., Evans, P.R., Teo, C.H., and Nagai, K. 1994. Crystal structure at $1.92 \AA$ resolution of the RNA-binding domain of the U1A spliceosomal protein complexed with an RNA hairpin. Nature 372: 432-438.

Page-McCaw, P.S., Amonlirdviman, K., and Sharp, P.A. 1999. PUF60: A novel $\mathrm{U}_{2} \mathrm{AF}^{65}$-related splicing activity. RNA 5: $1548-1560$.

Pang, Q., Hays, J.B., and Rajagopal, I. 1993. Two cDNAs from the plant Arabidopsis thaliana that partially restore recombination proficiency and DNA-damage resistance to E. coli mutants lacking recombination-intermediate-resolution activities. Nucleic Acids Res. 21: 1647-1653.

Pawson, T. and Nash, P. 2003. Assembly of cell regulatory systems through protein interaction domains. Science 300: 445-452.

Poleev, A., Hartmann, A., and Stamm, S. 2000. A trans-acting factor, isolated by the three-hybrid system, that influences alternative splicing of the amyloid precursor protein minigene. Eur. J. Biochem. 267: 4002-4010.

Potashkin, J., Naik, K., and Wentz-Hunter, K. 1993. U2AF homolog required for splicing in vivo. Science 262: 573-575.

Price, S.R., Evans, P.R., and Nagai, K. 1998. Crystal structure of the spliceosomal $\mathrm{U}_{2} \mathrm{~B}^{\prime \prime}-\mathrm{U} 2 \mathrm{~A}^{\prime}$ protein complex bound to a fragment of U2 small nuclear RNA. Nature 394: 645-650.

Query, C.C., Bentley, R.C., and Keene, J.D. 1989. A common RNA recognition motif identified within a defined U1 RNA binding domain of the 70K U1 snRNP protein. Cell 57: 89101.

Query, C.C., Moore, M.J., and Sharp, P.A. 1994. Branch nucleophile selection in pre-mRNA splicing: Evidence for the bulged duplex model. Genes \& Dev. 8: 587-597.

Rain, J.C., Rafi, Z., Rhani, Z., Legrain, P., and Kramer, A. 1998. Conservation of functional domains involved in RNA binding and protein-protein interactions in human and Saccharomyces cerevisiae pre-mRNA splicing factor SF1. RNA 4: 551-565.

Raju, G.P., Dimova, N., Klein, P.S., and Huang, H.C. 2003. SANE, a novel LEM domain protein, regulates bone morphogenetic protein signaling through interaction with Smad1. J. Biol. Chem. 278: 428-437.

Rosonina, E. and Blencowe, B.J. 2002. Gene expression: The close coupling of transcription and splicing. Curr. Biol. 12: R319-R321.

Rudner, D.Z., Kanaar, R., Breger, K.S., and Rio, D.C. 1996. Mutations in the small subunit of the Drosophila U2AF splicing factor cause lethality and developmental defects. Proc. Natl. Acad. Sci. 93: 10333-10337.

Rudner, D.Z., Breger, K.S., Kanaar, R., Adams, M.D., and Rio, D.C. 1998a. RNA binding activity of heterodimeric splicing factor U2AF: At least one RS domain is required for highaffinity binding. Mol. Cell. Biol. 18: 4004-4011.

Rudner, D.Z., Kanaar, R., Breger, K.S., and Rio, D.C. 1998 b. Interaction between subunits of heterodimeric splicing factor U2AF is essential in vivo. Mol. Cell. Biol. 18: 1765-1773.

Ruskin, B., Zamore, P.D., and Green, M.R. 1988. A factor, $\mathrm{U} 2 \mathrm{AF}$, is required for U2 snRNP binding and splicing complex assembly. Cell 52: 207-219.

Rutz, B. and Seraphin, B. 1999. Transient interaction of BBP/ ScSF1 and Mud2 with the splicing machinery affects the kinetics of spliceosome assembly. RNA 5: 819-831.

Sachs, A.B., Bond, M.W., and Kornberg, R.D. 1986. A single gene from yeast for both nuclear and cytoplasmic polyadenylate- 
binding proteins: Domain structure and expression. Cell 45: 827-835.

Sampath, J., Long, P.R., Shepard, R.L., Xia, X., Devanarayan, V., Sandusky, G.E., Perry III, W.L., Dantzig, A.H., Williamson, M., Rolfe, M., et al. 2003. Human SPF45, a splicing factor, has limited expression in normal tissues, is overexpressed in many tumors, and can confer a multidrug-resistant phenotype to cells. Am. J. Pathol. 163: 1781-1790.

Scherly, D., Boelens, W., van Venrooij, W.J., Dathan, N.A., Hamm, J., and Mattaj, I.W. 1989. Identification of the RNA binding segment of human U1 A protein and definition of its binding site on U1 snRNA. EMBO J. 8: 4163-4170.

Selenko, P., Gregorovic, G., Sprangers, R., Stier, G., Rhani, Z., Kramer, A., and Sattler, M. 2003. Structural basis for the molecular recognition between human splicing factors U2AF ${ }^{65}$ and SF1/mBBP. Mol. Cell 11: 965-976.

Shatkin, A.J. and Manley, J.L. 2000. The ends of the affair: Capping and polyadenylation. Nat. Struct. Biol. 7: 838-842.

Shen, H., Kan, J.L., and Green, M.R. 2004. Arginine-serine-rich domains bound at splicing enhancers contact the branchpoint to promote prespliceosome assembly. Mol. Cell 13: 367-376.

Shepard, J., Reick, M., Olson, S., and Graveley, B.R. 2002. Characterization of $\mathrm{U}_{2} \mathrm{AF}^{26}$, a splicing factor related to $\mathrm{U}_{2} \mathrm{AF}^{35}$. Mol. Cell. Biol. 22: 221-230.

Shi, H. and Xu, R.M. 2003. Crystal structure of the Drosophila Mago nashi-Y14 complex. Genes \& Dev. 17: 971-976.

Smith, C.W. and Valcarcel, J. 2000. Alternative pre-mRNA splicing: The logic of combinatorial control. Trends Biochem. Sci. 25: 381-388.

Thompson, J.D., Gibson, T.J., Plewniak, F., Jeanmougin, F., and Higgins, D.G. 1997. The CLUSTAL_X windows interface: Flexible strategies for multiple sequence alignment aided by quality analysis tools. Nucleic Acids Res. 25: 4876-4882.

Thornton, J.M., Todd, A.E., Milburn, D., Borkakoti, N., and Orengo, C.A. 2000. From structure to function: Approaches and limitations. Nat. Struct. Biol. 7: 991-994.

Tronchere, H., Wang, J., and Fu, X.D. 1997. A protein related to splicing factor $\mathrm{U}_{2} \mathrm{AF}^{35}$ that interacts with $\mathrm{U}_{2} \mathrm{AF}^{65}$ and SR proteins in splicing of pre-mRNA. Nature 388: 397-400.

Tupler, R., Perini, G., and Green, M.R. 2001. Expressing the human genome. Nature 409: 832-833.

Valcarcel, J., Gaur, R.K., Singh, R., and Green, M.R. 1996. Interaction of $\mathrm{U}_{2} \mathrm{AF}^{65} \mathrm{RS}$ region with pre-mRNA branch point and promotion of base pairing with U2 snRNA. Science 273: $1706-1709$.

Van Buskirk, C. and Schupbach, T. 2002. Half pint regulates alternative splice site selection in Drosophila. Dev. Cell 2: 343-353.

Varani, L., Gunderson, S.I., Mattaj, I.W., Kay, L.E., Neuhaus, D., and Varani, G. 2000. The NMR structure of the $38 \mathrm{kDa}$ U1A protein-PIE RNA complex reveals the basis of cooperativity in regulation of polyadenylation by human U1A protein. Nat. Struct. Biol. 7: 329-335.

Waite, K.A. and Eng, C. 2003. From developmental disorder to heritable cancer: It's all in the BMP/TGF- $\beta$ family. Nat. Rev. Genet. 4: 763-773.

Wang, X. and Tanaka Hall, T.M. 2001. Structural basis for recognition of AU-rich element RNA by the HuD protein. Nat. Struct. Biol. 8: 141-145.

Wang, X., McLachlan, J., Zamore, P.D., and Hall, T.M. 2002. Modular recognition of RNA by a human pumilio-homology domain. Cell 110: 501-512.

Wentz-Hunter, K. and Potashkin, J. 1996. The small subunit of the splicing factor $\mathrm{U} 2 \mathrm{AF}$ is conserved in fission yeast. Nucleic Acids Res. 24: 1849-1854.
Wu, J.Y. and Maniatis, T. 1993. Specific interactions between proteins implicated in splice site selection and regulated alternative splicing. Cell 75: 1061-1070.

Wu, J. and Manley, J. 1989. Mammalian pre-mRNA branch site selection by U2 snRNP involves base pairing. Genes \& Dev. 3: $1553-1561$.

Wu, S., Romfo, C.M., Nilsen, T.W., and Green, M.R. 1999. Functional recognition of the 3 ' splice site AG by the splicing factor $\mathrm{U}_{2} \mathrm{AF}^{35}$. Nature 402: 832-835.

Yan, D., Perriman, R., Igel, H., Howe, K.J., Neville, M., and Ares, M. 1998. CUS2, a yeast homolog of human Tat-SF1, rescues function of misfolded U2 through an unusual RNA recognition motif. Mol. Cell. Biol. 18: 5000-5009.

Zamore, P.D. and Green, M.R. 1989. Identification, purification, and biochemical characterization of U2 small nuclear ribonucleoprotein auxiliary factor. Proc. Natl. Acad. Sci. 86: $9243-9247$.

Zeng, Q. and Hall, K.B. 1997. Contribution of the C-terminal tail of U1A RBD1 to RNA recognition and protein stability. RNA 3: 303-314.

Zhang, M., Zamore, P.D., Carmo-Fonseca, M., Lamond, A.I., and Green, M.R. 1992. Cloning and intracellular localization of the U2 small nuclear ribonucleoprotein auxiliary factor small subunit. Proc. Nat1. Acad. Sci. 89: 8769-8773.

Zhou, Q. and Sharp, P.A. 1996. Tat-SF1: Cofactor for stimulation of transcriptional elongation by HIV-1 Tat. Science 274: 605-610.

Zhou, Z., Licklider, L.J., Gygi, S.P., and Reed, R. 2002. Comprehensive proteomic analysis of the human spliceosome. $\mathrm{Na}$ ture 419: 182-185.

Zhuang, Y. and Weiner, A. 1989. A compensatory base change in human U2 snRNA can suppress a branch site mutation. Genes \& Dev. 3: 1545-1552.

Zorio, D.A. and Blumenthal, T. 1999a. Both subunits of U2AF recognize the $3^{\prime}$ splice site in Caenorhabditis elegans. $\mathrm{Na}$ ture 402: 835-838.

- 1999b. U2AF ${ }^{35}$ is encoded by an essential gene clustered in an operon with RRM/cyclophilin in Caenorhabditis elegans. RNA 5: 487-494. 


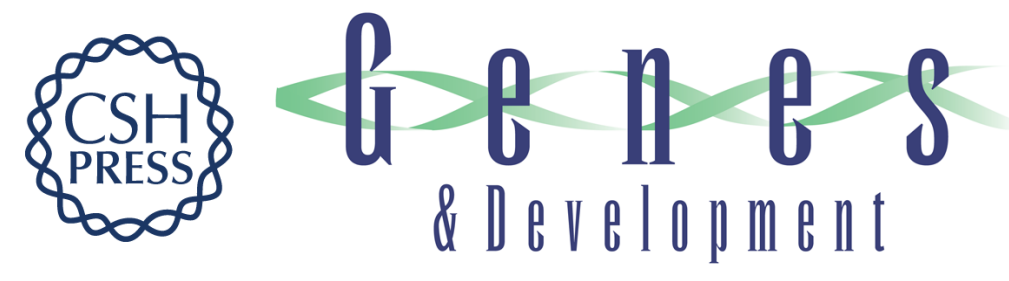

\section{U2AF homology motifs: protein recognition in the RRM world}

Clara L. Kielkopf, Stephan Lücke and Michael R. Green

Genes Dev. 2004, 18:

Access the most recent version at doi:10.1101/gad.1206204

References This article cites 111 articles, 49 of which can be accessed free at: http://genesdev.cshlp.org/content/18/13/1513.full.html\#ref-list-1

License

Email Alerting Receive free email alerts when new articles cite this article - sign up in the box at the top Service right corner of the article or click here.

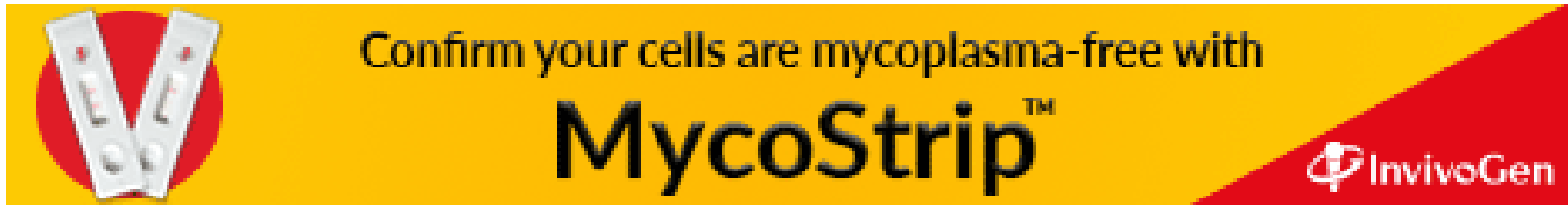

